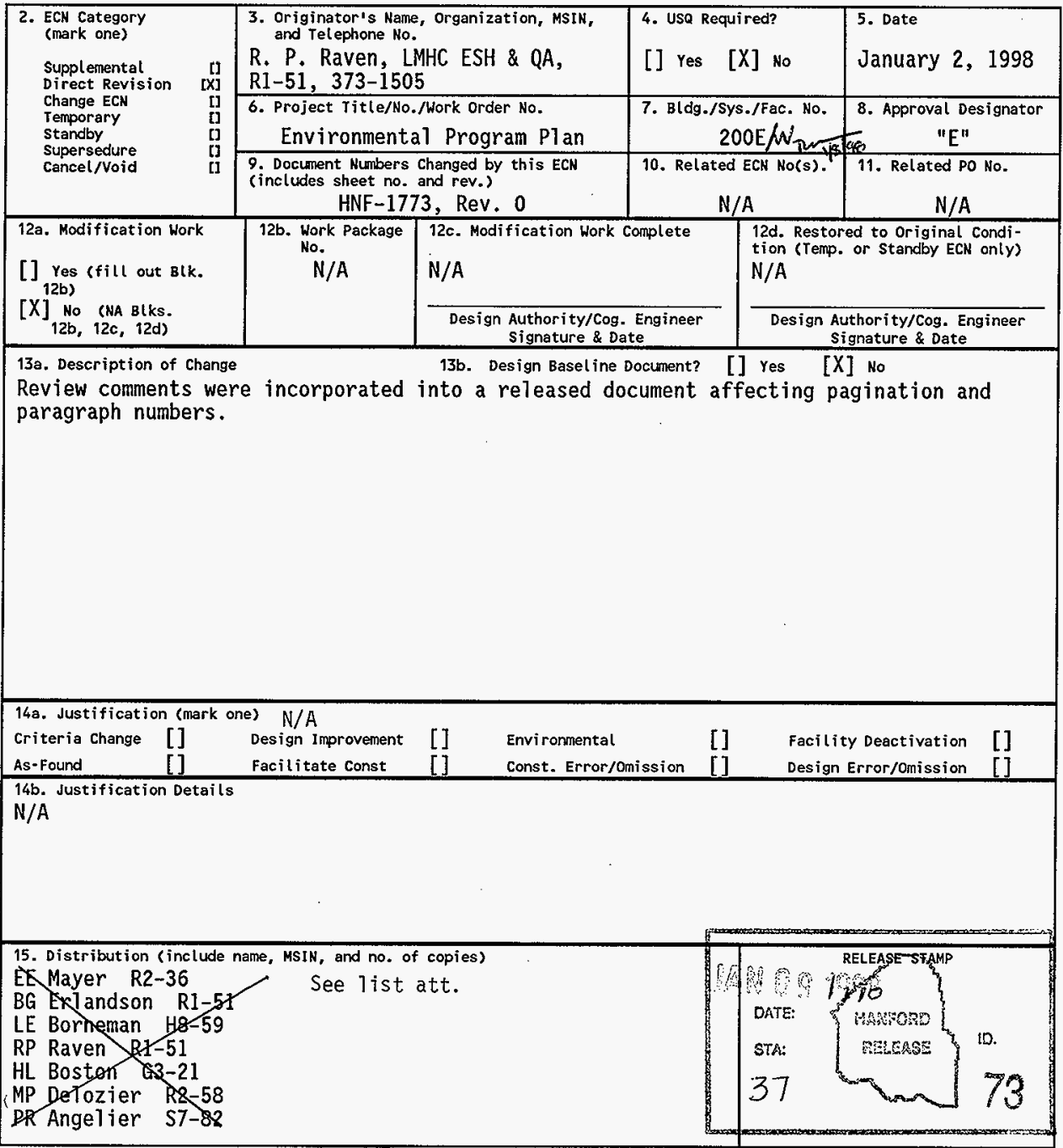




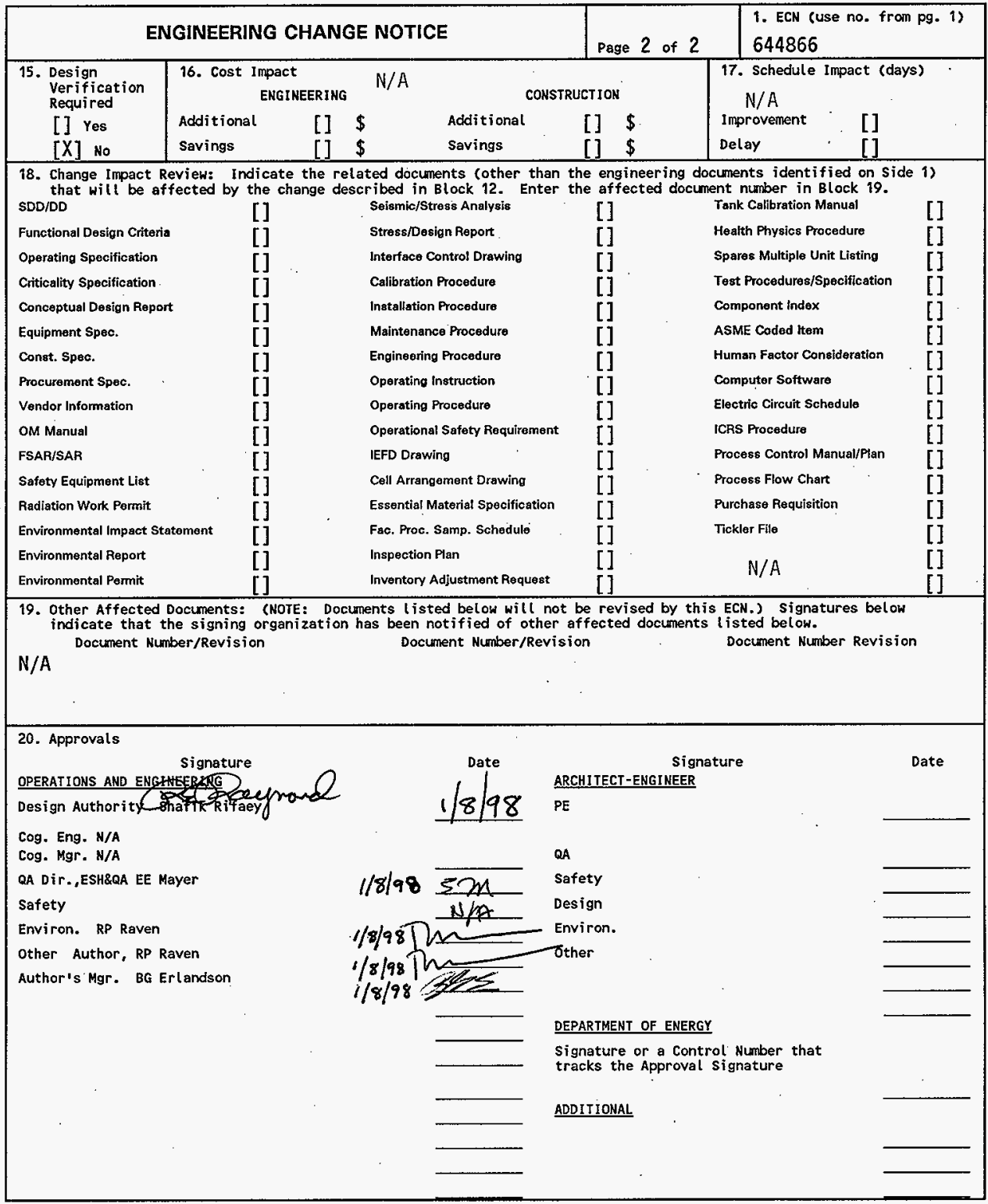




\section{Tank Waste Remediation System Environmental Program Plan}

Prepared for the U.S. Department of Energy

$\$$ Fluor Daniel Hanford, Inc.

Richland, Washington

Hanford Management and Integration Contractor for the

U.S. Department of Energy under Contract DE-AC-0696-RL13200

Approved for Public Release; Further Dissemination Unlimited 


\title{
Tank Waste Remediation System Environmental Program Plan
}

\author{
R.P. Raven
}

Lockheed Martin Hanford Company, Richland, WA 99352

U.S. Department of Energy Contract DE-AC06-96RL13200
EDT/ECN: 644866
Org Code:7B220
UC: 2030
B\&R Code: EW 3130010
Charge Code: D215P
Total Pages: 75,71 fan

Key Words: Environmental, TWRS

Abstract: This Environmental Program Plan has been developed in support of the Integrated Environmental, Safety and Health Management System and consistent with the goals of DOE/RL-96-50, Hanford Strategic Plan (RL 1996a), and the specifications and guidance for ANSI/ISO 14001-1996, Environmental Management Systems - Specification with guidance for use (ANSI/IS0 1996).

IRADEMARK DISCLAIMER. Reference herein to any specific comercial product, process, or service by trade name, trademark, manufacturer, or otherwise, does not necessarily constitute or imply its endorsement, recommendation, or favoring by the United States Government or any agency thereof or its contractors or subcontractors.

Printed in the United States of Anerica. To obtain copies of this document, contact: Document Control Services, P.0. BoX 950, Mailstop H6-08, Richland WA 99352, Phone (509) 372-2420;

Fax (509) $376-4989$.
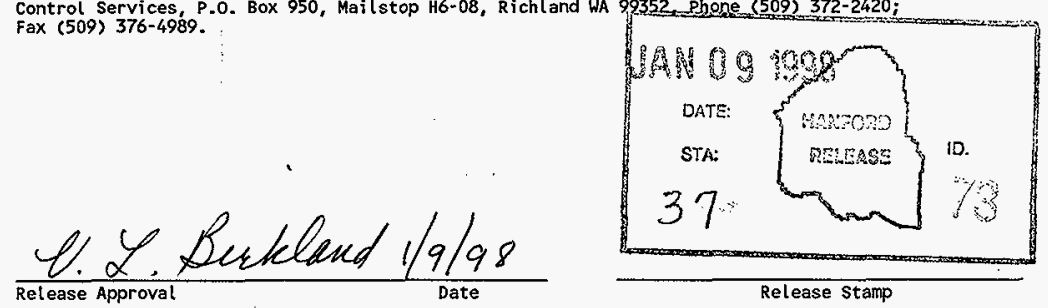

Approved for Public Release 
LEGAL DISCLAIMER

This report was prepared as an account of work sponsored by an agency of the United States Government. Neither the United States Government nor any agency thereof, nor any of their employees, nor any of their contractors,

subcontractors or their employees, makes any warranty. express or implied, or assumes any legal liability or responsibility for the accuracy, completeness, or any third party's use or the results of such use of any information, apparatus, product, or process disclosed, or represents that its use would not infringe privately owned rights.

Reference herein to any specific commercial product, process, or service by trade name, trademark,

manufacturer, or otherwise, does not necessarily constitute or imply its endorsement, recommendation, or favoring by the United States Government or any agency thereof or its contractors or subcontractors. The views and opinions of authors expressed herein do not necessarily state or reflect those of the United States Government or any agency thereof.

This report has been reproduced from the best available copy.

Available in paper copy and microfiche.

Available to the U.S. Department of Energy and its contractors from

U.S. Department of Energy

Office of Scientific and Technical information (OSTI)

P.O. Box 62

Oak Ridge, TN 37831

(615) $576-8401$

Available to the public from the U.S. Department of Commerce

National Technical Information Service (NTIS)

5285 Port Royal Road

Springfield, VA 22161

(703) 487-4650

Printed in the United States of America

DISCLM-1.CHP (8-95) 


\section{RECORD OF REVISION}

(1) Document Number
HNF-1773

Page 1

(2) Title TWRS Environmental Program Plan for M\&I Contractor Work Scope in Support of TWRS Phase IB Privatization

CHANGE CONTROL RECORD

\begin{tabular}{|c|l|}
\hline (3) Revision & (4) Description of Change - Replace, Add, and Delete Pages \\
\hline 0 & (7) EDT-605623, 11/12/97 \\
\hline 1 RS & Revision per ECN-644866 \\
\hline
\end{tabular}

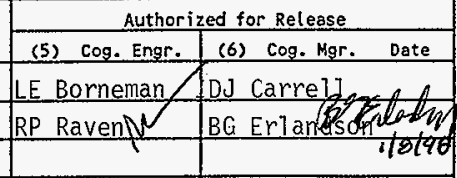


HNF-1773

UC-510

\title{
Tank Waste Remediation System Environmental Program Plan
}

\author{
L. E. Borneman
}

Fluor Daniel Hanford, Inc.

Date Published

January 1998

Prepared by Lockheed Martin Hanford Corporation

Richland, Washington

Prepared for the U.S. Department of Energy

\section{Cluor Daniel Hanford, Inc.

Richland, Washington

Hanford Management and Integration Contractor for the

U.S. Department of Energy under Contract DE-AC-0696-RL13200 
HNF-1773 Rev 1

This page intentionally left blank. 
Document Title: Tank Waste Remediation System Environmental Program Plan

Approved by:

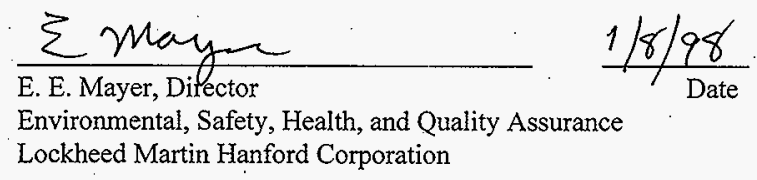


HNF-1773 Rev 1

This page intentionally left blank. 


\section{CONTENTS}

1.0 INTRODUCTION $\ldots \ldots \ldots \ldots \ldots \ldots \ldots \ldots \ldots \ldots \ldots \ldots \ldots \ldots \ldots$

2.0 ENVIRONMENTAL POLICY $\ldots \ldots \ldots \ldots \ldots \ldots \ldots \ldots \ldots \ldots \ldots \ldots$

3.0 ORGANIZATIONAL RESPONSIBILITIES $\ldots \ldots \ldots \ldots \ldots \ldots \ldots \ldots \ldots \ldots$

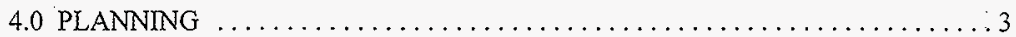

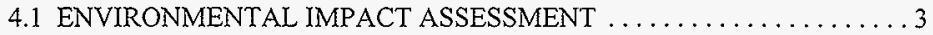

4.1.1 National Environmental Policy Act of $1969 \ldots \ldots \ldots \ldots \ldots$

4.1 .2 Related Laws . . . . . . . . . . . . . . . . . . . . 5

4.2 REQUIREMENTS MANAGEMENT . . . . . . . . . . . . 7

4.2.1 Project Hanford Management Contract Environmental

Requirements Management Process $\ldots \ldots \ldots \ldots \ldots \ldots$

4.2.2 Lockheed Martin Hanford Corporation Environmental

Requirements Management Process $\ldots \ldots \ldots \ldots \ldots \ldots \ldots$

4.3 ENVIRONMENTAL PERMIT PREPARATION . . . . . . . . . .

4.3.1 Resource Conservation and Recovery Act of $1976 \ldots \ldots \ldots$. . . . 8

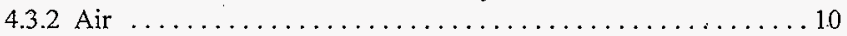

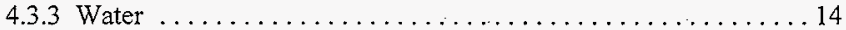

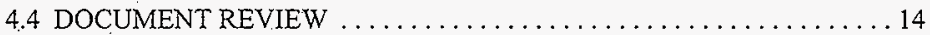

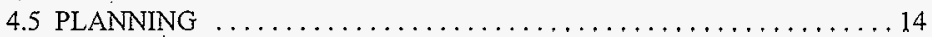

5.0 IMPLEMENTATION AND OPERATION $\ldots \ldots \ldots \ldots \ldots \ldots \ldots \ldots \ldots \ldots$

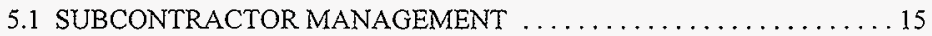

5.2 TRAINING, AWARENESS, AND COMPETENCE $\ldots \ldots \ldots \ldots \ldots \ldots$

5.2.1 Environmental Training and Awareness $\ldots \ldots \ldots \ldots \ldots \ldots$

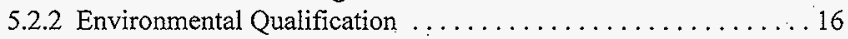

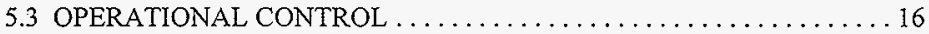

5.3.1 Procedure Upgrades to Reflect Changed Requirements or

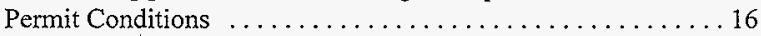

5.3.2 Implementation of Hanford Facility Resource Conservation

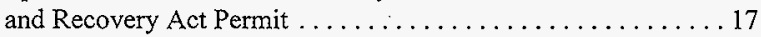

5.3.3 Solid Waste Management ................... 17

5.3.4 Double-Shell Tank System Waste Analysis . . . . . . . . . . 17

5.4 POLLUTION PREVENTION AND WASTE MINIMIZATION $\ldots \ldots \ldots 18$

5.5 UNDERGROUND STORAGE TANK MANAGEMENT $\ldots \ldots \ldots \ldots \ldots 18$

5.6 EMERGENCY PREPAREDNESS AND RESPONSE . . . . . . . . . 18

6.0 REPORTS, NOTIFICATIONS, AND RECORDS $\quad \ldots \ldots \ldots \ldots \ldots \ldots \ldots \ldots$

6.1 ENVIRONMENTAL REPORTS . . . . . . . . . . . . . . . . . 19

6.2 SPILL AND RELEASE REPORTING $\ldots \ldots \ldots \ldots \ldots \ldots \ldots \ldots \ldots$ 
CONTENTS (Continued)

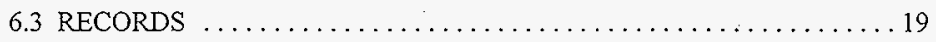

7.0 VERIFICATION AND CORRECTIVE ACTIONS . . . . . . . . . . . 19

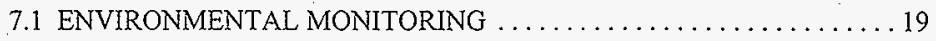

7.1.1 Effluent Monitoring ........................... 20

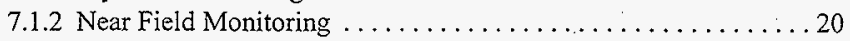

7.1 .3 Groundwater Monitoring $\ldots \ldots \ldots \ldots \ldots \ldots \ldots \ldots \ldots \ldots \ldots \ldots \ldots \ldots$

7.2 COMPLIANCE ASSESSMENT/CORRECTIVE ACTION

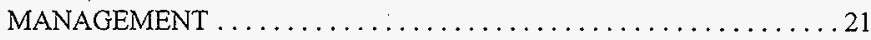

7.2.1 Surveillance/Compliance Inspections $\ldots \ldots \ldots \ldots \ldots \ldots \ldots 22$

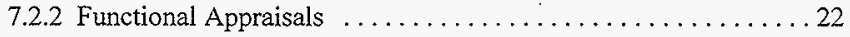

8.0 DECONTAMINATION AND DECOMMISSIONING $\ldots \ldots \ldots \ldots \ldots \ldots 23$

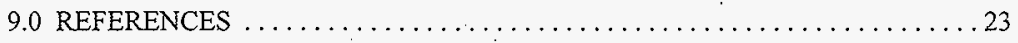

\title{
APPENDICES
}

\begin{abstract}
A READINESS TO PROCEED: PRELIMINARY PROJECT HANFORD MANAGEMENT CONTRACT PERMIT MODIFICATION SCHEDULE .. A-i

B INFORMATION NEEDED TO SUPPORT SITEWIDE REPORTING $\ldots .$. B-i

C IMPLEMENTING INSTRUCTIONS $\ldots \ldots \ldots \ldots \ldots \ldots \ldots \ldots \ldots \ldots$

D GUIDANCE AND REQUIREMENTS TO DELIVERABLES CROSSWALK $\ldots \ldots \ldots \ldots \ldots \ldots \ldots \ldots \ldots \ldots \ldots \ldots \ldots \ldots \ldots \ldots \ldots \ldots \ldots \ldots$
\end{abstract}

\section{LIST OF TABLES}

1. Tank Waste Remediation System Treatment, Storage, and Disposal Units. . . . . . 9

2. Tank Waste Remediation System Stacks. . . . . . . . . . . . . 12 


\section{LIST OF TERMS}

CFR

DOE

DST

Ecology

EIS

EPA

ES\&H

FDH

FEMP

FY

LAW

LMHC

NEPA

NESHAP

NOC

PHMC

PNNL

RCRA

RL

S/RID

SST

Tri-Party Agreement

TSD

TWRS

WAC

WDOH

WMH
Code of Federal Regulations

U.S. Department of Energy

double-shell tank

Washington State Department of Ecology

environmental impact statement

U.S. Environmental Protection Agency

environmental, safety, and health

Fluor Daniel Hanford, Inc.

Facility Effluent Monitoring Plan

fiscal year

low-activity waste

Lockheed Martin Hanford Corporation

National Environmental Policy Act of 1969

National Emission Standards for Hazardous Air Pollutants notice of construction

Project Hanford Management Contract

Pacific Northwest National Laboratories

Resource Conservation and Recovery Act of 1976

U.S. Department of Energy, Richland Operations Office standards/requirements identification documents single-shell tank

Hanford Federal Facility Agreement and Consent Order treatment, storage, and disposal

Tank Waste Remediation System

Washington Administrative Code

Washington State Department of Health

Waste Management Federal Services of Hanford, Inc. 
HNF-1773 Rev 1

This page intentionally left blank. 


\section{TANK WASTE REMEDIATION SYSTEM ENVIRONMENTAL PROGRAMI PLAN}

\subsection{INTRODUCTION}

Line management is responsible for the integration of environmental requirements into work planning. This Environmental Program Plan has been developed in support of the Integrated Environmental, Safety, and Health Management System (FDH 1997c) and consistent with the goals of DOE/RL-96-92, Hanford Strategic Plan (RL 1996a), and the specifications and guidance for ANSI/ISO 14001-1996, Environmental management systems--Specification with guidance for use (ANSI/ISO 1996). This plan is a "part of an overall management system that includes organizational structure, planning activities, responsibilities, practices, procedures, processes, and resources for developing, implementing, achieving, reviewing, and maintaining the environmental policy" (ANSI/ISO 1996).

\subsection{ENVIRONMENTAL POLICY}

It is the policy of Lockheed Martin Hanford Corporation (LMHC) that the corporation and our employees will be stewards of the environment. Protection of the environment, including protection of natural, archeological, cultural, and historical resources, and the public health, is a primary consideration in our activities. The LMHC is committed to achieving environmental excellence by systematically integrating environmental, safety, and health (ES\&H) principles across DE-AC06-96RL13200, Project Hanford Management Contract (PHMC) (RL 1996b).

To foster environmental stewardship, LMHC will do the following:

- Consider the impacts of our activities on the environment

- Comply with applicable laws, regulations, and directives

- Work together with Fluor Daniel Hanford, Inc. (FDH); other major subcontractors; U.S. Department of Energy, Richland Operations Office (RL); regulators; stakeholders; and the Indian Tribes to achieve the common goal of environmental excellence 
- Work with our customers and stakeholders to influence the development of responsible laws, regulations, and innovative programs to safeguard the environment and maintain a cost-effective and flexible business approach to completing the cleanup mission

- Integrate pollution prevention, resource conservation, waste minimization, and environmental impact considerations into our planning, decisionmaking, designs, training, and daily work activities

- Define and mitigate existing adverse environmental conditions and anticipate, eliminate, or mitigate future environmental impacts using a risk-based graded approach before they pose a threat to our environment

- Promptly report environmental incidents and deficiencies

- Continually assess our performance and implement opportunities to improve the environment

- Communicate our goals and progress to our employees, customers, and stakeholders.

This environmental policy places responsibility on top management for implementing the environmental program and reviewing performance against this policy. This environmental policy is a firm commitment of the LMHC management team to integrate environmental stewardship into daily operations.

The mission of the Tank Waste Remediation System (TWRS) Environmental Program is to do the following:

- Identify, document, and interpret environmental requirements as they apply to TWRS activities

- $\quad$ Establish compliance programs (i.e., develop procedures, permits, and reports necessary to maintain a compliant program)

- Assess compliance with applicable requirements, document, and correct deficiencies

- $\quad$ Support day-to-day operations activities (e.g., emissions monitoring and waste management)

- Provide strategic planning necessary to bring new facilities or processes on line. 


\subsection{ORGANIZATIONAL RESPONSIBILITIES}

The LMHC manages the TWRS Project under contract to FDH. The LMHC TWRS Environmental organization reports to the LMHC Director of ES\&H and Quality Assurance and is composed of two groups; Environmental Policy and Permitting and Operations Compliance. A third group, Generator Services, is matrixed to TWRS Environmental. Generator Services is a component of Waste Management Federal Services of Hanford, Inc. (WMH) and provides solid waste services to TWRS.

Individual programs and projects within TWRS directly fund environmental activities for implementation of requirements including the development of facility-specific permits, reports, and resolution of compliance issues. The TWRS Management Systems. Function provides funding for implementation of TWRS crosscutting activities including requirements management, planning and ścheduling of assessments, and corrective action management.

\subsection{PLANNING}

\subsection{ENVIRONMENTAL IMPACT ASSESSMENT}

\subsubsection{National Environmental Policy Act of 1969}

The environmental impacts of the TWRS Project have been assessed in two recent Environmental Impact Statements (EIS): DOE/EIS-0189, Tank Waste Remediation System, Hanford Site, Richland, Washington, Final Environmental Impact Statement (DOE and Ecology 1996), and DOE/EIS-0212, Final Environmental Impact Statement, Safe Interim Storage of Hanford Tank Wastes (Ecology and RL 1995).

Environmental impacts of field level work are assessed on an activity-by-activity basis as a part of the work planning process. Most routine work in the tank farms is covered by RL sitewide categorical exclusions for routine maintenance. Work that is not routine undergoes an environmental review and completion of documentation in accordance with site procedures.

4.1.1.1. Tank Waste Remediation System Environmental Impact Statement. The environmental impacts from the TWRS Project were evaluated by the U.S. Department of Energy (DOE) in the TWRS EIS (DOE and Ecology 1996). The TWRS EIS (DOE and Ecology 1996) addressed the management and disposal of current and projected waste stored in the 177 underground storage tanks (i.e, single- and double-shell tanks [SST and DST] and in approximately 60 active and inactive miscellaneous underground 
storage tanks that were associated with Hanford Site tank farm operations). In addition, the TWRS EIS (DOE and Ecology 1996) evaluated the management and potential disposal of approximately 1,930 cesium and strontium capsules currently on loan or stored at the Hanford Site.

In 62 FR 8693, "Record of Decision for the Tank Waste Remediation System; Hanford Site, Richland, WA," DOE selected the Phased Implementation, which entails the use of private contractors for specific portions of the TWRS scope. Phased implementation comprises the demonstration phase (Phase 1) and the full implementation phase (Phase 2). Phase 1 encompasses the following actions:

1. Continuing to safely manage tanks. This activity includes the replacement of certain waste transfer piping and routine maintenance activities for tank farm instrumentation, ventilation, and electrical systems. Safe storage also includes ongoing activities including conducting environmental and safety-related monitoring, removing pumpable liquids from the SSTs, mitigating flammable gas safety hazards, and transferring currently stored waste and newly generated waste using the replacement cross-site transfer line, rail cars, and tanker trucks

2. Constructing and operating demonstration facilities

3. Collecting additional information through tank waste and vadose zone characterization

4. Performing demonstrations of technologies that have the potential to reduce uncertainties associated with the TWRS Project (e.g., Hanford Tank Initiative).

In the TWRS EIS Record of Decision (62 FR 8693), DOE commits to the following National Environmental Policy Act of 1969 (NEPA) reviews:

1. Formal NEPA reviews of the entire TWRS Project will take place at the following stages:

a. Before proceeding into Privatization Phase 1, Part B (scheduled for May 1998)

b. Prior to the start of hot operation of Privatization Phase 1, Part B (scheduled for December 2002)

2. NEPA analysis of the upgrade of certain instrumentation, tank ventilation, and electrical systems to upgrade the regulatory compliance status of the current tank farm facilities (i.e., Project W-314) (Completed) 
3. Further NEPA documentation for site selection of privatization facilities

4. Further NEPA documentation addressing the onsite disposal of low-activity waste (LAW)

5. Further NEPA documentation addressing SST and DST system closure.

4.1.1.2 Safe Interim Storage Environmental Impact Statement. The environmental and human health impacts associated with the construction and operation of facilities and systems to continue the safe management of high-level, mixed radioactive wastes stored in tanks were evaluated in DOE/EIS-0212 (Ecology and RL 1995). In 60 FR 61687, "Record of Decision: Safe Interim Storage of Hanford Tank Wastes, Hanford Site, Richland, WA," DOE stated its decision to:

1. Operate the existing cross-site transfer system until replaced by a new cross-site transfer system that consists of buried, double-wall, insulated pipes (i.e., Project W-058)

2. Continue to operate the mixer pump installed in tank $24 I-S Y-10 I$ to mitigate the unacceptable accumulation of hydrogen and other flammable gases

3. Defer the decision on retrieval of solids from tank 241-SY-102 and limit transfers through that tank to noncomplexed wastes

4. Not build new DSTs at that time to mitigate the flammable gas safety issue.

\subsubsection{Related Laws}

The laws listed below are evaluated in conjunction with a NEPA evaluation of a proposed action. In addition, these reviews are required prior to granting a field excavation permit.

4.1.2.1 National Historic Preservation Act. In response to the National Historic Preservation Act, RL entered into a programmatic agreement with the Washington State Historic Preservation Office (DOE/RL-96-77, Programmatic Agreement Among the U.S. DOE-RL, the Advisory Council on Historic Preservation, and the Washington State Historic Preservation Office for the Maintenance, Deactivation, Alteration and Demolition of the Built Environment on the Hanford Site [RL 1996c]. The draft agreement commits to completing data collection and development of historical property inventory forms or extended historical property inventory forms for seven TWRS 
facilities. Each of the facilities was selected for its historical contribution, unique construction, or process application. The seven facilities are:

- $\quad 209-\mathrm{E} / 200 \mathrm{E}$, Critical Mass Laboratory

- 241-AW/200E, DST Tank Farm

- 241-T/200W, SST Tank Farm

- $\quad 241-\mathrm{TX} / 200 \mathrm{~W}, \mathrm{SST}$ Tank Farm

- 241-TY200W, SST Tank Farm

- 244-WR/200W, Storage

- 2707-AR/200E, Change House.

4.1.2.2 Section 106 Process - Cultural Resource Review. The RL approved a cultural resources exemption for the 18 TWRS tank farms in 1994 (9405630, Cultural Resources Exemption of the Tank Farm Areas [Crist 1994]). The basis for this exemption was the extensive disturbance caused by the installation of 177 DSTs and SSTs. The exemption covers construction and maintenance performed within 150 meters $(500 \mathrm{ft}$ ) of the 18 fenced tank farm areas and includes relocation of mobile offices. The exemption does not cover removal of tanks or demolition of permanent structures.

Excavation permits are required for activities that use mechanical means to dig below grade and for hand digging greater than $30 \mathrm{~cm}$ (12 in.) in depth. The excavation permit process requires a cultural resources review for projects not covered by the exemption.

Cultural Resource Reviews are conducted by the Hanford Cultural Resources Laboratory, Pacific Northwest National Laboratories (PNNL).

4.1.2.3 Endangered Species Act of 1973. Title 50, Code of Federal Regulations (CFR), Part 17, "Endangered and Threatened Wildlife and Plants," specifies the requirements for conducting reviews to determine whether a proposed project will have an impact on special status plant and animal species. A blanket biological review is conducted annualiy for general maintenance activities inside the 200 East and 200 West Area tank farms. The objective of the survey is to identify plant and animal species protected under the Endangered Species Act of 1973; candidates for protection and species listed as threatened, endangered, candidate, sensitive or monitor species by the State of Washington; and species protected under the Historic Migratory Bird Treaty Act of 1918. Recommendations are generally limited due to the highly disturbed nature of the area, but some recommendations are provided relative to protection of bird species.

Biological reviews are also required as part of the excavation permit process for activities not covered in the annual biological review process. Biological reviews are performed by PNNL. 
4.1.2.4 Wetland/Floodplain Requirements. A floodplain/wetland assessment must be conducted for proposed actions taking place within a floodplain/wetland and should be performed in conjunction with the NEPA process. However, since TWRS activities are not conducted within floodplain/wetlands, this requirement should not be applicable to TWRS projects under normal circumstances.

\subsection{REQUIREMENTS MANAGEMENT}

Integration of applicable environmental requirements with current and planned TWRS activities is necessary to satisfy legal and contractual commitments and is important to the implementation of a comprehensive environmental program.

Requirements activities include the identification of applicable requirements, assessment of impacts, maintenance of requirements documents, and implementation through TWRS operations and administrative documents and procedures.

Effective management of requirements involves routine interaction. with FDH's interpretive authority, RL programs, TWRS organizations, and regulators. Compliance of the TWRS Project with applicable environmental regulations is dependent upon having a structured approach to evaluating new and existing environmental requirements.

\subsubsection{Project Hanford Management Contract Environmental Requirements Management Process}

The Project Hanford Management Contract (PHMC) Environmental Triage

System is the starting point for entrance of environmental requirements into TWRS. The Triage System is located on the Hanford Intranet and performs the following key functions that ensure environmental requirements reach TWRS:

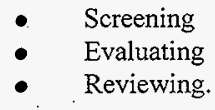

Although the Triage System is under development during fiscal year (FY) 1998, the screening function is being performed and is available for use.

The screening and evaluating functions are performed by FDH. New and modified regulations are screened for potential applicability to Hanford Site PHMC contractors and sub-contractors. The potentially applicable new or modified regulations are then evaluated for potential impacts to PHMC projects and Hanford Site contractors. This analysis is simultaneously posted in the Triage System (at http://apdev07.rl.gov/entr/default.asp) and sent to project reviewers for an evaluation of impacts. 
The TWRS reviewers access the triage system and examine the requirement and its respective regulatory analysis. If no regulatory analysis is provided, the TWRS reviewers will still evaluate the requirement for its impact on TWRS. The TWRS reviewers respond to the evaluator by posting their comments/feedback on the Triage System. If the requirement is not applicable to TWRS, the evaluators are so notified.

The evaluator then coordinates the reviewers' comments/feedback and modifies the regulatory analysî̀, if necessary. The final regulatory analysis is available for review on the Intranet. The final regulatory analysis, comment responses, and/or implementation plan are presented to the PHMC Environmental Managers and Environmental Compliance Officers for their approval.

\subsubsection{Lockheed Martin Hanford Corporation Environmental Requirements Mariagement Process}

When an environmental requirement is applicable to TWRS, the LMHC environmental subject matter expert will modify standards/requirements identification documents (S/RIDs) to incorporate the change. Depending on the urgency of the regulatory change, the S/RIDs can be updated immediately or during the regularly scheduled quarterly update. The environmental subject matter expert will help determine the implementing process for the new requirement and will ensure that implementing documentation resulting from the S/RIDs change is updated.

\subsection{ENVIRONMENTAL PERMIT PREPARATION}

Appendix $A$ of this document contains a preliminary schedule for permit application preparation or modifications required for the PHMC to support the privatization effort. When these schedules are updated, they will be incorporated into the project baseline.

\subsubsection{Resource Conservation and Recovery Act of 1976}

Washington State Department of Ecology (Ecology) and the U.S. Environmental Protection Agency (EPA) have issued WA7890008967, Hanford Facility RCRA Permit (Ecology and EPA 1994), which contains requirements for final status treatment, storage, and disposal (TSD) units at the Hanford Site. The Hanford Site is considered a single RCRA facility with numerous TSD units. There are two options for bringing a TSD unit into compliance, one for continued operation and one for closure. An individual dangerous waste permit application or closure plan has been or will be submitted for each TSD unit. Table 1 provides a list of TWRS-operated TSD units, the date of the most 
Table 1. Tank Waste Remediation System Treatment, Storage, and Disposal Units.

\begin{tabular}{|c|c|c|c|c|}
\hline TWRS facility & $\begin{array}{l}\text { Part A submitted } \\
\text { (latest rev.) }\end{array}$ & Part B submitted. & $\begin{array}{l}\text { Interim status } \\
\text { closure plan } \\
\text { submitted }\end{array}$ & Comments \\
\hline DST System . & $10 / 1 / 96^{\mathrm{a}}$ & $4 / 13 / 93^{b}$ & N/A & $\begin{array}{l}\text { Part B, Rev } 1 \\
\text { scheduled for } 6 / 99 \\
\text { submittal. }\end{array}$ \\
\hline SST System & $10 / 1 / 96^{3}$ & N/A & $11 / 30 / 96^{\circ}$ & $\begin{array}{l}\text { Submit Tank } \\
\text { Closure/Post- } \\
\text { Closure Plan for } \\
\text { selected closure } \\
\text { demonstrations }\end{array}$ \\
\hline $\begin{array}{l}\text { 204-AR Waste } \\
\text { Unloading Facility }\end{array}$ & $10 / 1 / 96^{a}$ & $6 / 99$ submittal & N/A & $\begin{array}{l}\text { Part B, Rev } 1 \\
\text { scheduled for } 6 / 99 \\
\text { submittal }\end{array}$ \\
\hline $\begin{array}{l}\text { Grout Treatment } \\
\text { Facility }\end{array}$ & $10 / 1 / 96^{d}$ & $\begin{array}{l}\text { on hold - project } \\
\text { canceled }\end{array}$ & N/A & $\begin{array}{l}\text { (LMHC custody of } \\
\text { non-DW vaults) }\end{array}$ \\
\hline 216-B-63 Trench & $10 / 1 / 96^{\mathrm{a}}$ & $\mathrm{N} / \mathrm{A}^{\circ}$ & $\begin{array}{l}6 / 30 / 95^{\mathrm{C}} \\
(\text { TPA M-20-36) }\end{array}$ & $\begin{array}{l}\text { Targeted for } \\
\text { transfer to BHI }\end{array}$ \\
\hline $\begin{array}{l}\text { Hanford Waste } \\
\text { Vitrification Plant }\end{array}$ & $10 / 1 / 96^{c}$ & project on hold & N/A & $\begin{array}{l}\text { (FDH custody of } \\
\text { Part. A) }\end{array}$ \\
\hline $\begin{array}{l}\text { 2727-WA Sodium } \\
\text { Reactor Experiment } \\
\text { Sodium Storage and } \\
\text { Treatment Facility } \\
\text { (decommissioned) }\end{array}$ & $10 / 1 / 96^{a}$ & $\begin{array}{l}\text { Pait A withdrawal } \\
\text { requested } 6 / 89 \\
(\text { TPA M-20-45) }\end{array}$ & N/A & $\begin{array}{l}\text { Facility is TWRS } \\
\text { custodianship, } \\
\text { Part A is being } \\
\text { withdrawn by } \\
\text { Waste Management } \\
\text { Hanford (requested } \\
6 / 89 \text {, TPA } \\
\text { M-20-45) }\end{array}$ \\
\hline
\end{tabular}

'RL, 1993, Hanford Facility Dangerous. Waste Part A Permit Application, DOE/RL-88-21, 3 vols., U.SDepartment of Energy, Richland Operations Office, Richland, Washington.

'RL, 1991, Double-Shell Tank System Dangerous Waste Permit Application, DOE/RL-90-39, Rev. 0, 3 vols., U.SDepartment of Energy, Richland Operations Office, Richland, Washington.

'Rl, 1996d, Single-Shell Tank Closure Work Plan, DOE/RL-89-16, Rev. 1, U.SDepartment of Energy, Richland Operations Office, Richland, Washington.

${ }^{\mathrm{J}} \mathrm{RL}, 1996 \mathrm{e}$, Grout Treatment Facility Dangerous Waste Permit Application, DOE/RL-38-27, Rev. 5, U.SDepartment of Energy, Richland Operations Office, Richland, Washington.

ERL, 1996f, Hanford Waste Vitrification Plant Dangerous Waste Permit Application, DOE/RL-89-02, Rev. 5, U.SDepartment of Energy, Richland Operations Office, Richland, Washington.

'Ecology et al, 1996, Hanford Federal Facility Agreement and Consent Order, 2 vols., Washington State Department of Ecology, U.S. Environmental Protection Agency, and U.S. Department of Energy, Olympia, Washington.

$\mathrm{BHI}=$ Bechtel Hanford, Inc.

DST $=$ double-shell tank.

DW = dangerous waste.

FDH = Fluor Daniel Hanford, Inc.

LMHC = Lockheed Martin Hanford Corporation.
$\mathrm{N} / \mathrm{A}=$ not applicable.

SST $=$ single-shell tank.

TPA $M=$ Tri-Party Agreement Milestone.

TWRS $=$ Tank Waste Remediation System . 
recent revision of the Part A permit application, and submittal date for the Part $B$ permit application or closure plan.

The TWRS Resource Conservation and Recovery Act of 1976 (RCRA) permitting is completed in accordance with schedules found in the Hanford Federal Facility Agreement and Consent Order (Tri-Party Agreement) (Ecology et al. 1996) Action Plan and the Hanford Site RCRA Permit (Ecology and EPA 1994).

4.3.1.1 Continued Operation. If there are plans to continue operation of the unit, a dangerous waste Part B permit application will be submitted to Ecology. The unit will continue to operate in compliance with interim status facility standards until the unit specific Part B permit application is included in the Hanford Facility RCRA Permit. Where TSD units do not meet interim status standards, necessary actions are identified to bring these units into compliance and are documented in Appendix D of the Hanford Federal Facility Agreement and Consent Order (Tri-Party Agreement) (Ecology et al. 1996).

Upon approval of a unit specific dangerous waste Part B permit application, Ecology will revise the Hanford Facility RCRA Permit to include the Part B permit application in Part III of the permit. The permit will be submitted to the public for review and comment and then the permit is issued to the $\mathrm{RL}$ and FDH. The unit specific section in Part III of the Hanford Facility RCRA Permit will contain specific operational requirements.

The TWRS operates RCRA facilities under interim status requirements and the Tri-Party Agreement (Ecology et al. 1996) and is in the process of preparing a Part B permit application for the DST System, which includes the 204-AR Waste Unloading Facility, to obtain final status. TWRS Environmental is responsible for the maintenance of TWRS Part A permit applications and preparation of Part B permit applications.

4.3.1.2 Closure. The TSD units that will cease operation in the near term will be operated in compliance with interim status standards until closure. The TWRS TSD units that cannot be operated in compliance with interim status standards have identified actions necessary to bring these TSD units into compliance in Appendix D of the Tri-Party Agreement (Ecology et al. 1996). Before closure, the unit must develop and submit a closure plan. The SST System is pursuing this path. 


\subsubsection{Air}

The LMHC TWRS Environmental organization develops or directs the development of radioactive and nonradioactive air emission permits needed to conduct routine maintenance, operations, and characterization activities. Key environmental documents are maintained, including WHC-EP-0479-1, Facility Effluent Monitoring Plan for Tank Farm Facility (Bachand and Crummel 1995), National Emission Standards for Hazardous Air Pollutants (NESHAP) stack designation, notices of construction (NOC) for specific activities, and input for a Hanford Site air operating permit and other reports. Applications to Ecology and the Washington State Department of Health (WDOH) are generally required to obtain approval for a given project.

The TWRS has several major and minor stacks. The TWRS, like other site projects, is not in compliance with NESHAP monitoring requirements for many of the major stacks and, therefore, entered into a Federal Facility Agreement and Consent Order for NESHAP Compliance (EPA 1994). The NESHAP Consent Order outlines the schedule for stack monitoring upgrades necessary to achieve compliance. The NESHAP Consent Order (EPA 1994) will be incorporated into a Hanford Site air operating permit. The TWRS stacks are listed in Table 2.

The TWRS receives multiple regulatory approvals each year for air emissions related to construction or new projects. The regulatory approvals and a compilation of their terms and conditions are found in Table IIB-1, "Regulations and Regulated Emissions," of DOE/RL-95-07, Hanford Site Air Operating Permit Application (RL 1995).

4.3.2.1 Radioactive Air Emissions (Notice of Construction) Applications. The WDOH administers the Radioactive Air Emissions Program as stated in Washington Administrative Code (WAC) 246-247, "Radiation Protection--Air Emissions." Approval to construct must be obtained prior to construction or facility modification. : Routine activities are not considered to be facility modifications and, therefore, do not require NOC approval.

The WDOH NOCs must address the following topics:

- Best Available Radionuclide Control Technology

- Demonstration of compliance with radionuclide emission standards in 40 CFR 61, "National Emission Standards for Hazardous Air Pollutants," Subpart H, "National Emission Standards for Emission of Radionuclides Other Than Radon From DOE Facilities," or WAC 173-480, "Ambient Air Quality Standards and Emissions Limits for Radionuclides,". whichever is more stringent, for emissions including those resulting from startup, shutdown, maintenance activities, or process upsets 
- $\quad$ Other topics as specified in WAC 246-247-110, "Appendix A-Application information requirements."

Once a NOC application is submitted, WDOH must inform RL within 30 days if additional information is required. Within 60 days of receipt of required information, the WDOH must issue an approval or denial to construct.

\subsubsection{National Emission Standards for Hazardous Air Pollutants Program Notice} of Construction Application. The EPA administers the NESHAP Program in the State of Washington in accordance with $40 \mathrm{CFR} 61$, Subpart $\mathrm{H}$, and addresses radioactive emissions.

Table 2. Tank Waste Remediation System Stacks.

\begin{tabular}{|c|c|c|c|c|c|}
\hline $\begin{array}{l}\text { Stack } \\
\text { Number }\end{array}$ & Facility & $\begin{array}{c}\text { Stack } \\
\text { Number }\end{array}$ & Facility & $\begin{array}{l}\text { Stack } \\
\text { Number }\end{array}$ & Facility \\
\hline \multicolumn{6}{|c|}{ - TWRS Major Stacks - NESHAP Compliant } \\
\hline $296-A-12$ & 244-AR Vessel Vent. & $296-A-42$ & $\begin{array}{l}\text { Aging Waste Project } \\
W \rightarrow 030\end{array}$ & 296-C-06 & $241-C-106$ \\
\hline $296-\mathrm{U}-11$ & 244.U DCRT & & & & \\
\hline \multicolumn{6}{|c|}{ TWRS Major Stacks - Addressed in NESHAP Compliance Agreement (EPA 1994) } \\
\hline $296-A-17$ & AY/AZ Primary Tank & $296-P-26$ & $\begin{array}{l}\text { AY/AZ Tank Backup } \\
\text { Ventilation }\end{array}$ & $296-\mathrm{A}-25$ & 244-A DCRT \\
\hline $296-\mathrm{B}-28$ & 244-BX DCRT & $296-C-5$ & 244-CR Vault & $296-P-16$ & 241-C-105/6 Tanks \\
\hline $296-S-22$ & 244-S DCRT & $296-\Upsilon-18$ & 244-TX DCRT . & & \\
\hline \multicolumn{6}{|c|}{ TWRS Minor Stacks } \\
\hline $296-A-13$ & $\begin{array}{l}\text { 244-AR Cell and } \\
\text { Canyon }\end{array}$ & $296-A-18$ & 241-AY-101 Annulus & $296-A-19$ & 241-AY-102 Annulus \\
\hline $296-\mathrm{A}-20$ & $\begin{array}{l}241-A Z-101 / 102 \\
\text { Annulus }\end{array}$ & $296-A-26$ & $\begin{array}{l}204 \text { AR Rail Car } \\
\text { Unloading. }\end{array}$ & $296-A-27$ & AW Primary Tanks \\
\hline $296-A-28$ & AW Annuli & 296-A-29 & AN Primary Tanks & $296-A-30$ & AN Annuli \\
\hline $296-A-40$ & AP Primary Tanks & $296-A-41$ & AP Annuli & $296-A-43$ & $\begin{array}{l}\text { Aging Waste Bldg } \\
(W-030)\end{array}$ \\
\hline $296-C-07$ & $\begin{array}{l}\text { 241-C-103 Vapor } \\
\text { Mixer System }\end{array}$ & $296-P-22$ & SY Annuli & $296-P-23$ & SY Primary Tanks \\
\hline $296-S-25$ & $\begin{array}{l}\text { SY Replacement } \\
\text { Exhauster. }\end{array}$ & $296-\mathrm{P}-31$ & 209-E Building & $296-\mathrm{P}-32$ & RMCS \#2 \\
\hline $296-\mathrm{P}-33$ & RMCS\# 3 & 296-P-34 & RMCS \#4 & $296-\$-15$ & RMCS in SX Farm \\
\hline
\end{tabular}


Table 2. Tank Waste Remediation System Stacks.

\begin{tabular}{|l|l||l|l||c|c|}
\hline \multicolumn{1}{|c|}{$\begin{array}{c}\text { Stack } \\
\text { Number }\end{array}$} & \multicolumn{1}{|c|}{ Facility } & $\begin{array}{c}\text { Stack } \\
\text { Number }\end{array}$ & \multicolumn{1}{|c|}{ Facility } & $\begin{array}{c}\text { Stack } \\
\text { Number }\end{array}$ & \multicolumn{1}{|c|}{ Facility } \\
\hline $\begin{array}{l}296-\mathrm{P}-35 \\
\text { through } \\
296-\mathrm{P}-40\end{array}$ & Blue Max & $296-\mathrm{P}-41$ & $\begin{array}{l}241-\mathrm{A}-101 \text { Portable } \\
\text { Exhauster }\end{array}$ & $296-\mathrm{S}-15$ & SX Tanks \\
\hline $296-\mathrm{S}-18$ & $242-$ S Evaporator & $296-\Upsilon-17$ & $242-\mathrm{T}$ Evaporatơ & $296-\mathrm{W}-03$ & $\begin{array}{l}\text { 213-W Waste } \\
\text { Compactor }\end{array}$ \\
\hline
\end{tabular}

Seattle, WA.

EPA, 1994, Federal Facility Agreement and Consent Order for NESHAP Compliance, Environmental Protection Agency,

DCRT $=$ double-contained receiver tank.

NESHAP = National Emission Standards for Hazardous Air Pollutants.

RMCS $=$ rotary mode core sampling.

TWRS $=$ Tank Waste Remediation System.

A NESHAP NOC must address the following topics:

- Proposed nature of the source

- Proposed size of the source

- Proposed design of the source

- Operating design capacity

- Method of operation (including process flow diagram)

- Emissionis control system

- Emissions release rates

- Offsite doses

- References.

The permitting process is the same as that specified in the WDOH NOC approval process. Specific background documentation requirements for the Approval to Construct include engineering studies, functional design criteria, conceptual design reports, and advanced conceptual design reports; and supporting documentation may include source-term estimates, emissions estimates, and design information.

\subsubsection{Toxic Air Pollutant Notice of Construction Application. An NOC approval} from Ecology is required prior to the establishment of any new source or emission unit or modification. Ecology administers the program in accordance with WAC 173-460, "Controls for New Sources of Toxic Air Pollutants."

A Toxic Air Pollutant NOC must include the following information:

- Project location

- Process description 
- Design and operating parameters

- Emissions-type and quantity

- Anticipated construction schedule

- Best available control technology assessment

- Demonstration that proposed emissions will not cause a violation of state or national ambient air quality standards

- Prevention of Significant Deterioration applicability form

- $\quad$ References.

Once an NOC application is submitted, Ecology must notify DOE if the application is complete or additional information is required. Ecology must make a final determination within 30 days of submittal date or date on which additional information is provided.

\subsubsection{Water}

The TWRS discharges noncontact cooling water and other uncontaminated water to the Treated Effluent Disposal Facility for disposal. The Treated Effluent Disposal Facility has Permit No. ST-4502, State Waste Discharge Permit 200 Area Treated Effluent Disposal Facility (W049-H) (Ecology 1995), for disposal. Liquid effluent discharged to the Treated Effluent Disposal Facility must comply with Ecology (1995) waste acceptance criteria.

Test water from maintenance, hydrotest, and construction is discharged to the ground in compliance with Permit No. 91NM-177, State Ground Discharge Permit for Hanford Site Test Water (Ecology 1991), for disposal. The TWRS complies with the terms and conditions of this permit for water disposal.

\subsection{DOCUMENT REVIEW}

The Cognizant Engineer or technical authority identifies the need for environmental review of documents, procedures, etc., in accordance with the guidance in PHMC and LMHC procedures. The TWRS personnel involved in planning and performing activities that are not routine are responsible for ensuring the activity is screened for environmental compliance. The TWRS Environmental organization provides 
comments to the Cognizant Engineer or technical authority regarding the environmental requirements for the work in question. The TWRS Environmental maniagement or qualified personnel provide environmental reviews and approvals.

\subsection{PLANNING}

The Hanford Annual Budget submittal is covered by HNF-MD-016, Annual Budget Submittal (FDH 1997a), and is the result of annual budget targets applied to the Site by the DOE. The final documents are provided to the DOE for eventual submittal to the U.S. Congress. The process for developing the annual budget and the supporting documents that contain technical, schedule, and cost data is covered by HNF-MD-017, Multi-Year Work Plan (FDH 1997b). The Hanford Annual Budget Submittal will result in a required update of the current fiscal year multi-year work plan based on the budgetary constraints imposed upon the baseline.

The PHMC also prepares summary documents that identify that portion of the total Annual Budget Submittal that is identified for implementation of ES\&H programs and requirements. These ES\&H Risk Assessments together with the contractor prioritization provide the DOE and Congress sufficient detail to support risk-based budget planning and decisions.

\subsection{IMPLEMENTATION AND OPERATION}

\subsection{SUBCONTRACTOR MANAGEMENT}

To ensure the appropriate level of TWRS subcontractor awareness of environmental issues and regulations, the function of "subcontractor management and oversight" was established. Subcontractor management functions include (1) communication of requirements and (2) assessments, inspections, and/or surveillance to ensure subcontractor compliance with environmental requirements.

\subsection{TRAINING, AWARENESS, AND COMPETENCE}

\subsubsection{Environmental Training and Awareness}

The LMHC provides environmental training to their employees through both Hanford General Employee Training and facility-specific training. Hanford General 
Employee Training provides training for general environmental awareness, waste minimization, and pollution prevention.

Facility- and job-specific training is provided by LMHC in HNF-SD-WM-TR-026, Tank Waste Remediation System Dangerous Waste Training Plan (Pohto 1997) for compliance with the training requirements of WAC 173-303, "Dangerous Waste Regulations," Section 330, "Personnel training." Job-specific training is identified in HNF-IP-0974, Tank Waste Remediation System Dangerous Waste Training Requirements Matrices (Hopkinson 1997). Updates to the Plan and Matrices are provided through Engineering Change Notice to document holders. The Plans address training requirements for personnel working at the LMHC-managed TSD units facilities in the 200 East Area, 200 West Area, and 600 Area.

The TWRS training program is designed to prepare employees to operate and maintain the tank farms in a safe, effective, efficient, and environmentally sound manner. In addition to preparing employees to operate and maintain the tank farms under normal conditions, the training program ensures that employees are prepared to respond in a prompt and effective manner should abnormal or emergency conditions occur. Emergency response training is consistent with emergency responses outlined in the Building Emergency Plans.

\subsubsection{Environmental Qualification}

The LMHC requires technical staff authorized to provide environmental approvals to undergo a qualification program as described in HNF-IP-0842, TWRS Administration, Volume III, "Training," Section 10.3, "Technical Staff Qualification" (LMHC 1997). This qualification program will ensure that technical staff personnel possess the knowledge and skills necessary to perform their assigned duties in a safe, efficient, and cost-effective manner. The Facility Environmental Professional qualification process ensures candidates can demonstrate knowledge of environmental specific requirements (e.g., air emissions, NEPA, Tri-Party Agreement [Ecology et al. 1996]) and demonstrate the ability to perform specific environmental work tasks (e.g., perform satellite accumulation areas assessment, NEPA screening, work package review, facility walk downs). 


\subsection{OPERATIONAL CONTROL}

\subsubsection{Procedure Upgrades to Reflect Changed Requirements or Permit Conditions}

As permit conditions are imposed on TWRS and as new or changed regulations become effective, the TWRS Environmental organization will work with the affected organization to (1) brief their personnel about the changed requirement, (2) modify procedures, and (3) modify other affected documentation. In conjunction with working with the affected organization to properly implement the new requirement, the LMHC TWRS Environmental organization will initiate modifications to the facility S/RIDs.

Procedure modification in TWRS is governed by administrative procedures. An effective process to quickly modify procedures to implement compliance requirements is the procedure change authorization process. This process can be used to clarify the implementation of existing requirements. New requirements that significantly change work practices follow a more comprehensive administrative process.

Field implementation of regulatory approvals related to air permits is found in HNF-IP-0842, Volume VI, "Environmental," Section 1.2, "Field Implementation of Environmental Notices of Construction for Air Emission Units Operated by TWRS". (LMHC 1997).

\subsubsection{Implementation of Hanford Facility Resource Conservation and Recovery Act Permit}

The conditions of the Hanford Facility RCRA Permit (Ecology and EPA 1994) that apply to the specific units are defined in the Permit Applicability Matrix, Attachment 3 to the permit. The tank farms, while RCRA Interim Status facilities, are required to comply with the following conditions of Ecology and EPA (1994):

- I.A.1.a through I.A.1.b - "Effect of Permit"

- II.U.1 through II.U.4 - "Mapping of Underground Lines"

- II.V - "Marking of Underground Lines"

- II.X.1 through II.X.2 - "Schedule Extensions." 


\section{HNF-1773 Rev 1}

\subsubsection{Solid Waste Management}

The WMH is contracted by FDH to manage waste after it is generated by a facility or activity. The LMHC manages satellite accumulation areas and wastegenerating activities and provides access to WMH for containers, inspections, and field verification.

The WMH is responsible for the operation and management of the less than 90 -day pads and low-level waste/transuranic management areas at the $209 \mathrm{E}$ Building. The WMH develops portfolios, performs any necessary waste sampling and field verification, and schedules shipments to TSD facilities. The LMHC provides oversight for waste management activities in TWRS.

\subsubsection{Double-Shell Tank System Waste Analysis}

The WHC-SD-WM-EV-053, Double-Shell Tank Waste Analysis Plan (Mulkey 1996), is used to ensure the collection of adequate information for the safe handling of waste entering the DST System. The DST Waste Analysis Plan relies on documents like the Compatibility Data Quality Objectives to determine what information is required for safe handling of the incoming waste. Waste transfers from non-tank farm facilities are evaluated to ensure compliance. Each generator must provide a waste profile that documents waste composition and identifies applicable regulatory requirements.

\subsection{POLLUTION PREVENTION AND WASTE MINIMIZATION}

The WMH, under contract to FDH, develops and implements the Pollution Prevention and Waste Minimization Program. The LMHC implements Pollution Prevention and Waste Minimization through procedures governing the generation of waste and the re-use of equipment and supports development of pollution-prevention opportunity assessments.

\subsection{UNDERGROUND STORAGE TANK MANAGEMENT}

The LMHC operates four underground diesel fuel tank systems subject to the requirements of WAC 173-360, "Underground Storage Tank Regulations." Underground petroleum storage tank systems are expected to meet material, design, corrosion, leak-detection, spill, and overfill requirements of this regulation. Tank 
systems not meeting these requirements must be upgraded or closed no later than December 22, 1998. Three of the four tanks and the four piping runs do not meet the requirements of WAC 173-360 and will either be upgraded or removed before December 22, 1998.

\subsection{EMERGENCY PREPAREDNESS AND RESPONSE}

The TWRS Environmental organization administers the TWRS Emergency Preparedness program. This program is responsible for interfacing between the Site Emergency Preparedness contractor (Dyncorp Tri-Cities Services, Inc.), the integrating contractor (FDH), and the Operations organization. The TWRS Emergency Preparedness organization has developed scenarios and objectives for medium- to large-scale drills based on the TWRS hazards assessment and has an annual schedule to execute these exercises. The TWRS Emergency Preparedness organization is also responsible for updating its program manuals and WHC-IP-0263-TF, Tank Farms Building Emergency Plan (Rowland 1994) and for training the members of the TWRS Emergency Response Organization, including Personnel Accountability Aides, Staging Area Managers, Building Emergency Directors and Radiological Control and Safety support personnel. The TWRS Emergency Preparedness organization also works with the TWRS Training organization to ensure training objectives for drill exercises are identified and met. The Emergency Preparedness organization develops scenarios as a part of Operational Readiness Reviews and restart operations.

\subsection{REPORTS, NOTIFICATIONS, AND RECORDS}

\subsection{ENVIRONMENTAL REPORTS}

Environmental reports are required by various regulations. Generally these reports are sitewide in nature. The TWRS Environmental organization prepares inputs to these reports. Appendix B of this document outlines the reports and the types of information required to be submitted by the Hanford Site. Completion dates are estimates based on FY 1997 activities.

\subsection{SPILL AND RELEASE REPORTING}

Spills and releases are immediately reported to the Tank Farm Operations Shift Manager, who then initiates and coordinates response actions. One of the response actions the Shift Manager takes is to notify the TWRS Environmental Operations Compliance organization. The TWRS Environmental Operations Compliance 
organization informs the LMHC ES\&H and Quality Assurance Director and notifies FDH, Environmental Integration of the spill or release. The FDH is responsible for determining the reportability of spills and reporting them to $\mathrm{R} L$ and the regulatory agencies.

\subsection{RECORDS}

Timely environmental recordkeeping and reporting is required to demonstrate regulatory compliance. Environmental regulations require that certain documents, procedures, and data are retrievable within specified periods of time. The TWRS Environmental organization supports regulator requests for such records. A new TWRS procedure is being developed to clearly identify what these documents are and where they are stored. In addition, TWRS is participating in a sitewide initiative to scan these records into a computer database.

\subsection{VERIFICATION AND CORRECTIVE ACTIONS}

\subsection{ENVIRONMENTAL MONITORING}

Environmental monitoring of the Hanford Site consists of (1) effluent monitoring and (2) environmental surveillance including groundwater monitoring. Effluent monitoring for TWRS facilities is performed by LMHC either at the facility or at the point of release to the environment. Environmental surveillance consists of sampling and analyzing environmental media on and off the Hanford Site to detect and quantify potential contaminants and to assess their environmental and human health significance. Environmental surveillance of the Hanford Site is conducted by the PNNL under contract to the DOE.

\subsubsection{Effluent Monitoring}

Liquid and airborne effluent that may contain radioactive or hazardous constituents are monitored. The LMHC performs monitoring mainly through analyzing samples collected near points of release into the environment. Tank Farms has a FEMP (Bachand and Crummel 1995), which is associated with DOE/RL-91-50, Environmental Monitoring Plan, U.S. Department of Energy, Richland Operations Office (RL 1997), as required by DOE Order 5400.1, General Environmental Protection Program, for any operation that involves hazardous materials and radioactive substances that could impact employee or public safety or the environment. 
The Facility Effluent Monitoring Plans (FEMPs) assess effluent monitoring systems and evaluate whether they are adequate to ensure the public health and safety. The FEMPs ensure long-range integrity of the effluent-monitoring systems by requiring updates whenever new processes or operations introduce new hazardous materials or significant radioactive materials. The FEMPs are reviewed annually and are updated at a minimum of every three years. A FEMP is required for several tank farm facilities because of the NESHAP regulations specified in $40 \mathrm{CFR} 61$, Subpart $\mathrm{H}$.

\subsubsection{Near Field Monitoring}

Several types of environmental media are sampled near nuclear facilities to monitor the effectiveness of waste management and restoration activities and effluent treatment and control practices. Environmental monitoring is defined as routine monitoring near facilities that have the potential to discharge or have discharged, stored, or disposed of radioactive or hazardous contaminants. Monitoring locations are associated mostly with major nuclear facilities such as tank farms.

Much of the monitoring program consists of collecting and analyzing environmental samples and methodically surveying areas near waste sites and facilities releasing effluents and waste streams. The program also evaluates acquired analytical data, determines the effectiveness of facility effluent monitoring and controls, and detects and monitors unusual conditions. The program implements applicable portions of DOE Orders 5400.1; 5484.1, Environmental Protection, Safety, and Health Protection; 5400.5, Radiation Protection to the Public and the Environment; and 5820.2A, Radioactive Waste Management. The program is conducted by FDH and WMH under the PHMC (RL 1996b) for DOE.

\subsubsection{Groundwater Monitoring}

The DSTs have not leaked to the environment. Therefore, the DST system is not a unit for which groundwater monitoring is required by WAC 173-303-645 (1)(b), " "Release from regulated units." (i.e., not operated as a dangerous waste surface impoundment, waste pile, land treatment unit, or a landfill as defined in WAC 173-303-040, "Definitions."). Groundwater monitoring requirements found in WAC 173-303-806 (4)(a)(xx), "Final facility permits." required for this unit:

Some SSTs have leaked to the environment; therefore, the unit requires groundwater monitoring in accordance with WAC 173-303-645. The SST System is subdivided into waste management areas for groundwater monitoring as required by interim status regulations specified in $40 \mathrm{CFR} 265$, "Interim Status Standards for Owners and Operators of Hazardous Waste Treatment, Storage, and Disposal Facilities," Subpart F, "Groundwater Monitoring." 
Elevated contaminant levels have been detected for the following seven waste management areas, and they are undergoing Phase 1 assessment monitoring:

- A-AX Waste Management Area (i.e., A and AX SST Farm)

- $\quad$ B-BX-BY Waste Management Area (i.e., B, BX and BY SST Farms)

- C Waste Management Area (i.e., C SST Farm)

- TX-TY Waste Management Area (i.e., TX and TY SST Farm)

- T Waste Management Area (i.e., T SST Farm)

- $\quad$ S-SX Waste Management Area (i.e., S and SX SST Farm)

- U Waste Management Area (i.e., U SST Farm).

\subsection{COMPLIANCE ASSESSMENT/CORRECTIVE ACTION MANAGEMENT}

The LMHC Environmental organization has a responsibility for verifying that LMHC activities are conducted in an environmentally safe and sound manner and in compliance with applicable environmental protection program requirements. The compliance verification program provides timely information needed to identify items or areas requiring (or potentially requiring) attention and allows appropriate corrective actions to be identified and implemented by responsible management.

The environmental compliance verification program has been developed to ensure this responsibility is fulfilled. The program is a multi-level program designed to provide LMHC management with information needed to ensure environmental protection. It is implemented in accordance with the requirements of DOE orders and plans and uses the following compliance verification processes.

\subsubsection{Surveillance/Compliance Inspections}

Surveillance/Compliance Inspections are performed by the TWRS Environmental organization adhering to a schedule that is compiled monthly. The Inspection program is implemented under HNF-IP-0842, Volume VI, Section 2.1, "Scheduling, Planning, and Conducting Surveillance/Compliance Inspections" (LMHC 1997). The Surveillance/Compliance Inspections are coordinated with other assessment-type programs and are performed in parallel to reduce the impact on facility resources.

\subsubsection{Functional Appraisals}

A procedure for functional appraisals is currently being developed. The procedure will be incorporated into HNF-IP-0842, Volume VI (LMHC 1997). An 
assessment schedule will be developed and implemented. Previously, informal functional assessments were conducted using an internal checklist.

The LMHC conducts routine inspections of tank farm facilities to maintain compliance and to evaluate operations and maintenance activities. These routine inspections are documented in various ways including operator round sheets and container deficiency reports. Periodic inspections are also conducted by Environmental Field Representatives to identify deficiencies. Identified deficiencies are reported verbally or by informal documentation to the facility management for correction. In the future, these inspections will be considered part of the Surveillance Compliance Inspection Program, with deficiencies documented accordingly.

Indeperdent assessments are conducted by the FDH Facility Evaluation Board annually and are documented via written report to the company president. Environmental programs are specifically evaluated by the Facility Evaluation Board.

\subsection{DECONTAMINATION AND DECOMMISSIONING}

Planning to support TWRS decontamination and decommissioning activities is recognized as a programmatic function of TWRS Environmental organization. As detailed design criteria are developed for decontamination and decommissioning, they will be factored into permitting schedules. The RCRA closure plans will be the framework to document closure decisions.

\subsection{REFERENCES}

\section{Code of Federal Regulations}

40 CFR 61, "National Emission Standards for Hazardous Air Pollutants," Code of Federal Regulations, as amended.

40 CFR 265, "Interim Status Standards for Owners and Operators of Hazardous Waste. Treatment, Storage, and Disposal Facilities," Code of Federal Regulations, as amended.

50 CFR 17, "Endangered and Threatened Wildlife and Plants," Code of Federal Regulations, as amended. 
HNF-1773 Rev 1

Acts

Endangered Species Act of 1973, as amended, 16 USC 1531 et seq.

Historic Migratory Bird Treaty Act of 1918, as amended, 16 USC 703 et seq.

National Environmental Policy Act of 1969, as amended, 42 USC 4321 et seq.

National Historic Preservation Act, as amended, 16 USC 470 et seq.

Resource Conservation and Recovery Act of 1976, as amended, 42 USC 6901 et seq.

\section{U.S. Department of Energy Orders}

DOE Order 5400.1, General Environmental Protection Program,U.S. Department of Energy, Washington, D.C.

DOE Order 5400.5, Radiation Protection to the Public and the Environment,

U.S. Department of Energy, Washington, D.C.

DOE Order 5484.1, Environmental Protection, Safety, and Health Protection, U.S. Department of Energy, Washington, D.C.

DOE Order 5820.2A, Radioactive Waste Management, U.S. Department of Energy, Washington, D.C.

\section{Federal Register.}

60 FR 61687, 1995, "Record of Decision: Safe Interim Storage of Hanford Tank Wastes, Hanford Site, Richland, WA" Federal Register, Vol. 60, pp. 61687-61692 (December 1).

62 FR 8693, 1997, "Record of Decision for the Tank Waste Remediation System, Hanford Site, Richland, WA" Federal Register, Vol. 62, pp. 8693-8704 (February 26).

\section{Washington Administrative Code}

WAC 173-303, "Dangerous Waste Regulations," Washington Administrative Code, as amended. 
WAC 173-360, "Underground Storage Tank Regulations," Washington Administrative Code, as amended.

WAC 173-460, "Controls for New Sources of Toxic Air Pollutants," Washington Administrative Code, as amended.

WAC 173-480, "Ambient Air Quality Standards and Emissions Limits for Radionuclides," Washington Administrative Code, as amended.

WAC 246-247, "Radiation Protection--Air Emissions," Washington Administrative Code, as amended.

\section{Documents}

ANSI/ISO, 1996, Environmental management systems--Specification with guidance for use, ANSI/ISO 14001-1996, American National Standards Institute, New York, New York.

Bachand, D. D., and G. M. Crummel, 1995, Facility Effluent Monitoring Plan for Tank Farm Facility, WHC-EP-0479-1, Westinghouse Hanford Company, Richland, Washington.

Crist, M. E., 1994, Cultural Resources Exemption of the Tank Farm Areas (letter 9405630 to W. B. Brancroft, Westinghouse Hanford Company; August 16), U.S. Department of Energy, Richland Operations Office, Richland, Washington.

DOE and Ecology, 1996, Tank Waste Remediation System, Hanford Site, Richland, Washington, Final Environmental Impact Statement, DOE/EIS-0189, U.S. Department of Energy and Washington State Department of Ecology, Washington, D.C.

Ecology, 1995, State Waste Discharge Permit 200 Area Treated Effluent Disposal Facility (Project W-049F), Permit No. ST-4502, Washington State Department of Ecology, Olympia, Washington.

Ecology, 1991, State Ground Discharge Permit for Hanford Site Test Water, Permit No.91NM-177, Washington State Department of Ecology, Olympia, Washington.

Ecology and EPA, 1994, Hanford Facility RCRA Permit, WA7890008967, as modified, Washington State Department of Ecology and U.S. Environmental Protection Agency, Olympia, Washington. 
Ecology, EPA; and DOE, 1996, Hanford Federal Facility Agreement and Consent Order, 2 vols., Washington State Department of Ecology, U.S. Environmental Protection Agency, and U.S. Department of Energy, Olympia, Washington.

Ecology and RL, 1995, Final Environmental Impact Statement, Safe Interim Storage of Hanford Tank Wastes, DOE/EIS-0212, Washington State Department of Ecology and U.S. Department of Energy, Richland Operations Office, Lacey, Washington.

EPȦ, 1994, Federal Facility Agreement and Consent Order for NESHAP Compliance, U.S. Environmental Protection Agency, Seattle, Washington.

FDH, 1997a, Annual Budget Submittal, HNF-MD-016, Rev. 0, Fluor Daniel Hanford, Inc., Richland, Washington.

FDH, 1997b, Multi-Year Work Plan, HNF-MD-017, Rev. 0, Fluor Daniel Hanford, Inc., Richland, Washington.

FDH, 1997c, Integrated Environment, Saftey, and Health Management System Plan, HNF-MP-003, Rev. 0, Fluor Daniel Hanford, Inc., Richland, Washington.

Hopkinson, W. G., 1997, Tank Waste Remediation System Dangerous Waste Training Requirements Matrices, HNF-IP-0974, Rev. 9, prepared by Lockheed Martin Hanford Corporation for Fluor Daniel Hanford, Inc., Richland, Washington.

LMHC, 1997, TWRS Administration, HNF-IP-0842, Fluor Daniel Hanford, Inc., Richland Washington.

Mulkey, C. H., 1996, Double-Shell Tank Waste Acceptance Plan, WHC-SD-WM-EV-053, Rev. 4, Westinghouse Hanford Company, Richland; Washington.

Pohto, R. E., 1997, Tank Waste Remediation System Dangerous Waste Training Plan, HNF-SD-WM-TR-026, Rev. 6, prepared by Lockheed Martin Hanford Corporation for Fluor Daniel Hanford, Inc., Richland, Washington.

RL, 1997, Environmental Monitoring Plan, United States Department of Energy, Richland Operations Office, DOE/RL-91-50, Rev. 2, U.S. Department of Energy, Richland Operations Office, Richland, Washington.

RL, 1996a, Hanford Strategic Plan, DOE/RL-96-92, Rev. 0, U.S. Department of Energy, Richland Operations Office, Richland, Washington.

RL, 1996b, Project Hanford Management Contract (PHMC), DE-AC06-96RL13200, U.S. Department of Energy, Richland Operations Office, Richland, Washington. 
RL, 1996c, Programmatic Agreement Among the U.S. DOE-RL, the Advisory Council on Historic Preservation, and the Washington State Historic Preservation Office for the Maintenance, Deactivation, Alteration and Demolition of the Built Environment on the Hanford Site, DOE/RL-96-77, U.S. Department of Energy, Richland Operations Office, Richland, Washington.

RL, 1996d, Single-Shell Tank Closure Work Plan, DOE/RL-89-16, Rev. 1, U.S. Department of Energy, Richland Operations Officè, Richland, Washington.

RL, 1996e, Grout Treatment Facility Dangerous Waste Permit Application, DOE/RL-88-27, Rev. 5, U.S. Department of Energy, Richland Operations Office, Richland, Washington.

RL, 1996f, Hanford Waste Vitrification Plant Dangerous Waste Permit Application, DOE/RL-89-02, Rev. 5, U.S. Department of Energy, Richland Operations Office, Richland, Washington.

RL, 1995, Hanford Site Air Operating Permit Application, DOE/RL-95-07, Rev. 0, U.S. Department of Energy, Richland Operations Office, Richland, Washington.

RL, 1993, Hanford Facility Dangerous Waste Part A Permit Application, DOE/RL-8821, U.S. Department of Energy, Richland Operations Office, Richland, Washington.

RL, 1991, Double-Shell Tank System Dangerous Waste Permit Application; DOE/RL-90-39, U.S. Department of Energy, Richland Operations Office, Richland, Washington.

Rowland, D. J, 1994, Tank Farms Building Emergency Plan, WHC-IP-0263-TF, Rev. 2, Westinghouse Hanford Company, Richland, Washington. 
HNF-1773 Rev 1

This page intentionally left blank. 
HNF-1773 Rev 1

\section{APPENDIX A}

READINESS TO PROCEED: PRELIMINARY

PROJECT HANFORD MANAGEMENT CONTRACT

PERMIT MODIFICATION SCHEDULE 
HNF-1773 Rev 1

This page intentionally left blank. 


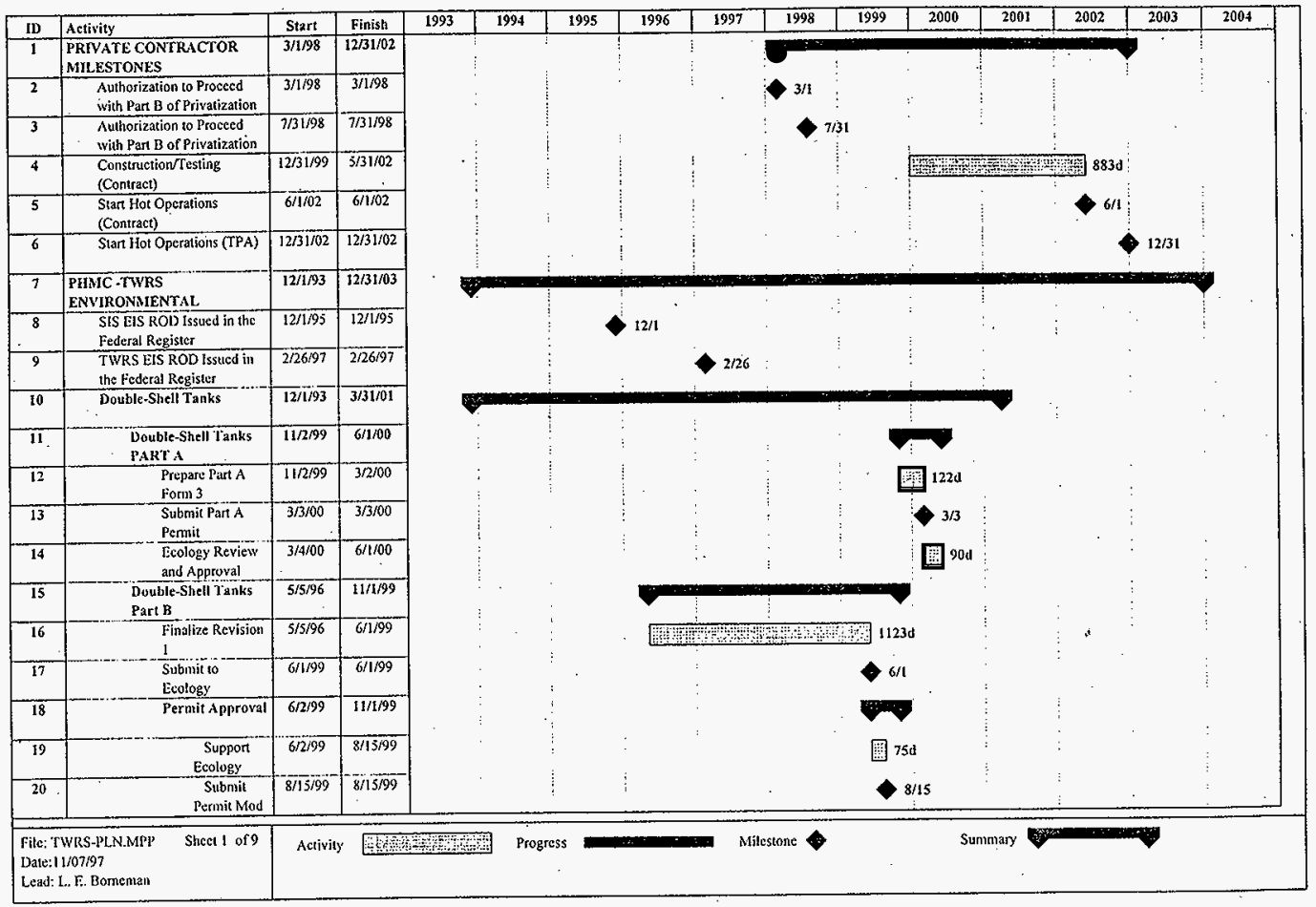




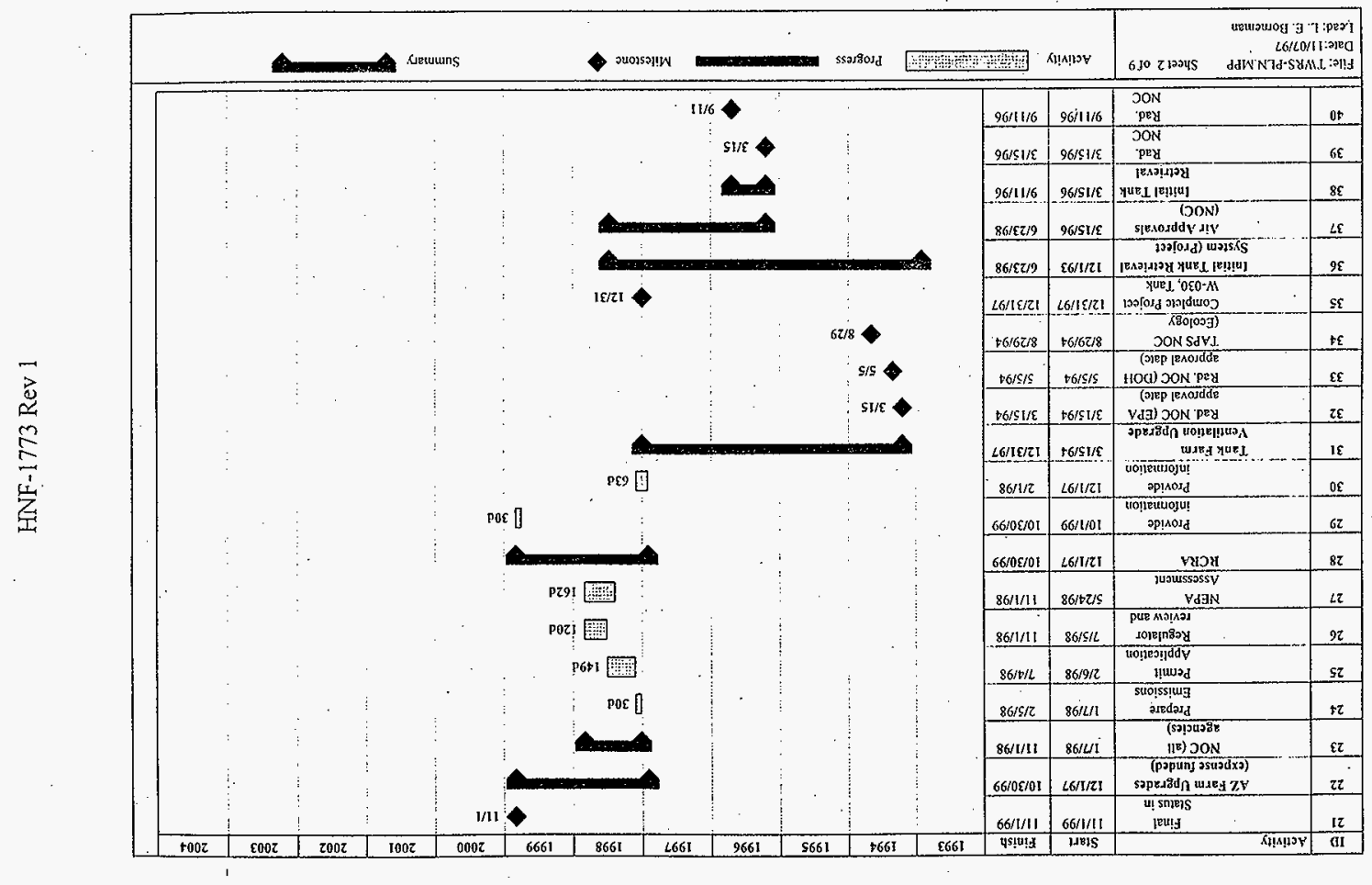




\begin{tabular}{|c|c|c|c|c|c|c|c|c|c|c|c|c|c|c|c|c|}
\hline 10 & Aetivity & Start & Finish & 1993 & 1994 & 1995 & 1996 & 1997 & 199 & 1999 & 200 & & & 002 & 2003 & 2004 \\
\hline 41 & $\begin{array}{l}\text { Noc-Pit, } \\
\text { line and }\end{array}$ & \begin{tabular}{|l|}
$12 / 23 / 97$ \\
\end{tabular} & $12233 / 97$ & & & & & & 122 & 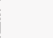 & & & : & & & 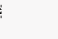 \\
\hline 42 & $\begin{array}{l}\text { NOC. } \\
\text { Pump }\end{array}$ & $6 / 23798$ & $6 / 23 / 98$ & & & & & & & & $i$ & ! & + & & : & \\
\hline 43 & $\begin{array}{l}\text { Cultural Review } \\
\text { Complete) }\end{array}$ & $12 / 1 / 23$ & $12 / / 193$ & & $12 / 4$ & & & & & & 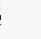 & $i$ & & & & \\
\hline 44 & $\begin{array}{l}\text { Tank Farm } \\
\text { Restoration and Safe }\end{array}$ & $12 / 1 / 93$ & $3 / 31 / 01$ & & & & & & & & & & & & . & : \\
\hline 45 & $\begin{array}{l}\text { NOC (AN Valve } \\
\text { Pit Upgradt) }\end{array}$ & $1 / 297$ & 61/1/97 & & & & & $\because$ & & & & $\vdots$ & : & & & \\
\hline 46 & $\begin{array}{l}\text { Preparts } \\
\text { Limissions }\end{array}$ & $1 / 7 / 97$ & $2 / 3 / 97$ & & & . & & (1) 300 & : & & $\vdots$ & : & & & & \\
\hline 47 & $\begin{array}{l}\text { Permit } \\
\text { Application }\end{array}$ & $2 / 6197$ & $7 / 4 / 97$ & & & & & 国 & & & 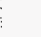 & & & & & \\
\hline 18 & $\begin{array}{l}\text { Regulator } \\
\text { review and }\end{array}$ & $7 / 5 / 97$ & $13 / 197$ & & & & & & 1200 & & & & & & & \\
\hline 49 & $\begin{array}{l}\text { Cultural Review } \\
\text { [Complecte] }\end{array}$ & 816094 & $8 / 16 ; 94$ & & & & & & & & & & & & & \\
\hline 50 & $\begin{array}{l}\text { Ecological } \\
\text { Raview }\end{array}$ & 328899 & $3 / 28,95$ & & & $3 / 28$ & & . & & & & & & & & \\
\hline 51 & $\begin{array}{l}\text { NEEA } \\
\text { Supplement }\end{array}$ & \begin{tabular}{|l|l|}
$9 / 21 / 96$ \\
\end{tabular} & $3 / 1 / 97$ & & & & & $9 / 21$ & & & & . & & & & \\
\hline 52 & $\begin{array}{l}\text { TPA Alilestones } \\
\text { ror W-314 }\end{array}$ & \begin{tabular}{|l|}
$12 / 1 / 93$ \\
\end{tabular} & $3 / 3170$ & & & & & & & & & & & & & \\
\hline 53 & $\begin{array}{l}\text { Start } \\
\text { Constuction }\end{array}$ & $6 / 30 / 99$ & 630199 & & & & & & & & & & & & & . \\
\hline 54 & $\begin{array}{l}\text { Start } \\
\text { Consiruction }\end{array}$ & \begin{tabular}{|l|}
$6 / 30,00$ \\
\end{tabular} & $6 / 3060$ & & & & & & & & & & & & & \\
\hline 55 & $\begin{array}{l}\text { Sian } \\
\text { Construction }\end{array}$ & $\mid 3 / 31 / 01$ & $3 / 31 / 21$ & & & & & & & & & $\rightarrow$ & & 4 & & \\
\hline 56 & $\begin{array}{l}\text { Start } \\
\text { Construction }\end{array}$ & $12 / 193$ & $12 / / 1 / 23$ & & $12 / 1$ & & & & & & & : & - & & & \\
\hline 57 & $\begin{array}{l}\text { Start } \\
\text { constraction }\end{array}$ & $12 / 1903$ & \begin{tabular}{|l|l|}
$12 / 1 / 93$ \\
\end{tabular} & & $12 / 1$ & & & & & & : & & & & & \\
\hline 58 & $\begin{array}{l}\text { Tank 241-C-106 } \\
\text { Retrieszl (Project }\end{array}$ & $2 / 23194$ & $10 / 3197$ & & & & & & 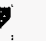 & & & & & & & \\
\hline 59 & $\begin{array}{l}\text { Cullural Review } \\
\text { [Complete] }\end{array}$ & $8 / 16194$ & $8 / 16914$ & & & & & & & & . & & & & $\vdots$ & \\
\hline 60 & $\begin{array}{l}\text { Ecological } \\
\text { Reviest }\end{array}$ & $3 / 28195$ & 328,5 & & & $3 / 28$ & & & & & : & & : & & & \\
\hline $\begin{array}{l}\text { Fitciti } \\
\text { Dare: } \\
\text { Lead: }\end{array}$ & $\begin{array}{l}\text { WRS.Pl.N.MPP Sheet } 3 \text { of } 9 \\
\text { i/ro7/97. } \\
\text { 1. E: Bomeman }\end{array}$ & Activiny & Wente & $2 x+42$ & & & & & ilestione & & & Sumsiary & & & & \\
\hline
\end{tabular}




\begin{tabular}{|c|c|c|c|c|c|c|c|c|c|c|c|c|c|c|c|}
\hline ID & Activily & Start & Finish & 1993 & 1994 & 1995 & 1996 & 1997 & 1928 & 1999 & 2000 & 2001 & 2002 & 2003 & 2004 \\
\hline 61 & NOC Phase I & $2 / 23 / 94$ & $2 / 28 / 94$ & & & & & & & & & & & & \\
\hline 62 & $\begin{array}{l}\text { Rad.NOC } \\
\text { (EPA }\end{array}$ & $2 / 23 / 94$ & $2 / 23 / 94$ & & $2 / 23$ & & & & & & & . & & 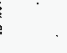 & \\
\hline 63 & $\begin{array}{l}\text { Rad. NOC } \\
\text { (DOH }\end{array}$ & $2 / 23 / 94$ & $2 / 23 / 94$ & & $2 / 23$ & & & & & & & & & : & \\
\hline 64 & $\begin{array}{l}\text { TAPS NOC } \\
\text { (Ecology }\end{array}$ & $2 / 28 / 94$ & $2 / 28 / 94$ & & $2 / 28$ & & & & & & & & : & . & \\
\hline 65 & Noc Phase it & $2 / 23 / 94$ & $10 / 6 / 85$ & & & & . & & & & & & & . & \\
\hline 66 & $\begin{array}{l}\text { Rad. NOC } \\
\text { (EPA }\end{array}$ & $2 / 23 / 94$ & $2 / 23 / 94$ & & 23 & & & & & & & & & $\vdots$ & \\
\hline 67 & $\begin{array}{l}\text { Rad. NOC } \\
\text { (DOH }\end{array}$ & $7 / 31 / 95$ & $7 \longdiv { 3 1 / 9 5 }$ & & & & & & & & & & & 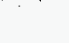 & \\
\hline 68 & $\begin{array}{l}\text { TAPS NOC } \\
\text { (Licology }\end{array}$ & $10 / 6 / 95$ & $10 / 6 / 95$ & & & & $10 / 6$ & & & & & & : & . $\cdot$ & \\
\hline 69 & $\begin{array}{l}\text { Initiate Sluiciag } \\
\text { of C.106 TPA }\end{array}$ & $10 / 31 / 97$ & $10 / 31 / 97$ & & & & & & $10 / 31$ & & & & & . & \\
\hline 70 & $\begin{array}{l}\text { Aw Jumper } \\
\text { Mlanifold Uipgrade }\end{array}$ & $2 / 25 / 94$ & $3 / 28 / 95$ & & & & & & & & & & & & \\
\hline 71 & $\begin{array}{l}\text { Ecological } \\
\text { Review } \\
\end{array}$ & $3 / 28 / 95$ & $3 / 28 / 95$ & & & 28 & & & & & & . & . & . & \\
\hline 72 & $\begin{array}{l}\text { Cultural Review } \\
\text { Complecel }\end{array}$ & $8 / 16 / 94$ & $8116 / 94$ & & & & & & & & & & & & \\
\hline 73 & $\begin{array}{l}\text { NEPA } \\
\text { Assessment . }\end{array}$ & $2 / 25 / 94$ & $2 / 25 / 94$ & & $2 / 25$ & & & & & & & & & : & \\
\hline 74 & $\begin{array}{l}\text { PHMIC Infrastructure } \\
\text { Project (Project W-5ig) }\end{array}$ & $12 / 1 / 97$ & $5 / 31 / 98$ & & & & & & & & & & & & \\
\hline 75 & Ecological Review & $4 / 2 / 98$ & $5 / 31 / 98$ & & & & & & 6. $60 \mathrm{~d}$ & & & & & & \\
\hline 76 & Cultural Review & $4 / 2 / 98$ & $5 / 31 / 98$ & & & & $\cdot$ & & $60 \mathrm{~d}$ & & & & & & \\
\hline 77 & $\begin{array}{l}\text { NEPA Suppliment } \\
\text { Alzalysis of TWRS EIS }\end{array}$ & $12 / 1 / 97$ & $5 / \mathrm{t} / \mathrm{98}$ & & & & & & $162 \mathrm{~d}$ & & & & & & \\
\hline 78 & $\begin{array}{l}\text { Solidified ligh-lecel } \\
\text { Waste Interim Storage }\end{array}$ & $4 / 1 / 97$ & $6 / 19 / 02$ & . & & & & & & & & & & & \\
\hline 79 & $\begin{array}{l}\text { Canister Storage } \\
\text { Building AIR }\end{array}$ & $4 / 1 / 97$ & $11 / 27 / 27$ & & & & & & & & & & . & & \\
\hline 80 & $\begin{array}{l}\text { Evaluate } \\
\text { Applicability of }\end{array}$ & $4 / 1 / 97$ & 7130997 & & & & & ⿶i: & & & & & $\vdots$ & & \\
\hline $\begin{array}{l}\text { File: } \\
\text { Date: } \\
\text { Lcad: }\end{array}$ & $\begin{array}{l}\text { WRS-PLNARPP Shect } 4 \text { of } 9 \\
\text { A/007/97 } \\
\text { E. Bordenian }\end{array}$ & Activity & BF & $6 \ldots$ & Pro & & & & sione 4 & & & mmary & & & \\
\hline
\end{tabular}




\begin{tabular}{|c|c|c|c|c|c|c|c|c|c|c|c|c|c|c|c|c|}
\hline ID & Aclivity & Start & Finish & 1993 & 1994 & 1995 & 1996 & 1997 & 1998 & 1999 & 2000 & 2001 & 200 & 002 & 2003 & 2004 \\
\hline 81 & $\begin{array}{l}\text { Regulator review } \\
\text { and approval . }\end{array}$ & $7 / 31 / 97$ & $11 / 27 / 97$ & 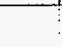 & & & & & $120 \mathrm{~d}$ & & ؛ & & & & & \\
\hline 82 & $\begin{array}{l}\text { Canister Storage } \\
\text { Building Delisting }\end{array}$ & $10 / 1 / 97$ & $6 / 1 / 02$ & . & & & & & & & & & & & . & \\
\hline 83 & $\begin{array}{l}\text { Develop } \\
\text { Delisting Petition }\end{array}$ & $10 / 1 / 97$ & $8 / 3 / 98$ & . & & $\cdot$ & & & 3 & & & & & : & & \\
\hline 84 & $\begin{array}{l}\text { Submit Petition } \\
\text { to EPA }\end{array}$ & $6 / 1 / 01^{\circ}$ & $6 / 1 / 01$ & & & & & & & & . & & & $\vdots$ & & \\
\hline 85 & $\begin{array}{l}\text { EPA Processes } \\
\text { Delisting Petition }\end{array}$ & $6 / 2 / 01$ & $6 / 1 / 02$ & & & 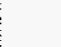 & & . & & & & P & 3 & 3654 & & \\
\hline 86 & $\begin{array}{l}\text { Canister Storage } \\
\text { Buitling PART A }\end{array}$ & $6 / 2 / 98$ & $6 / 30 / 99$ & : & & & & & & & & & & & & \\
\hline 87 & $\begin{array}{l}\text { Notice Of Intent } \\
\text { (Nol) }\end{array}$ & $6 / 2 / 98$ & $10 / 3 / 98$ & & & & & & & $124 d$ & & & & & & \\
\hline 88 & Public Review & $10 / 4 / 98$ & $3 / 2 / 99$ & : & & . & & & & $150 \mathrm{~d}$ & & & & & & \\
\hline 89 & $\begin{array}{l}\text { PART A Permit } \\
\text { Application }\end{array}$ & $11 / 1 / 98$ & $3 / 3 / 99$ & & & & & & & 1230 & & & & & & \\
\hline 90 & $\begin{array}{l}\text { TPA Milestone } \\
\text { M-90-12 for CSB }\end{array}$ & $6 / 30 / 99$ & $6 / 30 / 99$ & 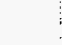 & & & & & & & 130 & & & & & \\
\hline 91 & $\begin{array}{l}\text { Ecology Review } \\
\text { and Approval }\end{array}$ & $3 / 4 / 99$ & $6 / 1 / 99$ & & & & & & : & 90 & & & & & & \\
\hline 92 & $\begin{array}{l}\text { Canister Storage } \\
\text { Building PART B }\end{array}$ & $10 / 108$ & $6 / 19 / 02$ & 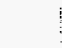 & & & & & & & & & & & & \\
\hline 93 & $\begin{array}{l}\text { Prepare Part B } \\
\text { Permit }\end{array}$ & 101198 & $5 / 20 / 00$ & 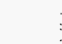 & & & & & & काm & $598 \mathrm{~d}$ & & & 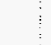 & & \\
\hline 94 & $\begin{array}{l}\text { Submil Pernit } \\
\text { Application }\end{array}$ & $9 / 30 / 00$ & $9 / 30 / 00$ & ; & & & & & & & & & & & & \\
\hline 95 & $\begin{array}{l}\text { TPA Milestone } \\
\text { M20-56 Submit }\end{array}$ & $12 / 31 / 00$ & $12 / 31 / 00$ & 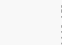 & & & & & $\vdots$ & & & $12 / 31$ & & & & \\
\hline 96 & Worksliops & $1 / 1 / 01$ & $10 / 30 / 01$ & 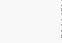 & & & & & $\cdot$ & & & \% & 3034 & " & & \\
\hline 97 & $\begin{array}{l}\text { P'repare Paut B } \\
\text { Permit } \\
\end{array}$ & $10 / 3101$ & $6 / 18 / 02$ & 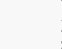 & & & & & & & & & : & 2314 & & \\
\hline 98 & $\begin{array}{l}\text { Submit Permit } \\
\text { Application }\end{array}$ & $6 / 19102$ & $6 / 19 / 02$ & 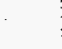 & & & & & & & & & & & & \\
\hline 29 & $\begin{array}{l}\text { Canister Storage } \\
\text { Building NITPA }\end{array}$ & $12 / 22 / 00$ & $6 / 1 / 01$ & & & & & & & & & 162 & & & & \\
\hline 100 & $\begin{array}{l}\text { Linualisilized Low-Activity } \\
\text { Waste (Project W-465) }\end{array}$ & $9 / 8 / 97$ & $12 / 31 / 03$ & & & & & & & & & & & & & \\
\hline $\begin{array}{l}\text { File: T } \\
\text { Date:1 } \\
\text { Lead: }\end{array}$ & $\begin{array}{l}\text { WRS-PLN.MPP Sheet } 5 \text { of } 9 \\
1 / 07 / 97 \\
\text { L. E. Borncman }\end{array}$ & Activity & min & 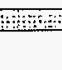 & P & ess & & & uston: & & & amary & & & 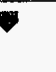 & \\
\hline
\end{tabular}




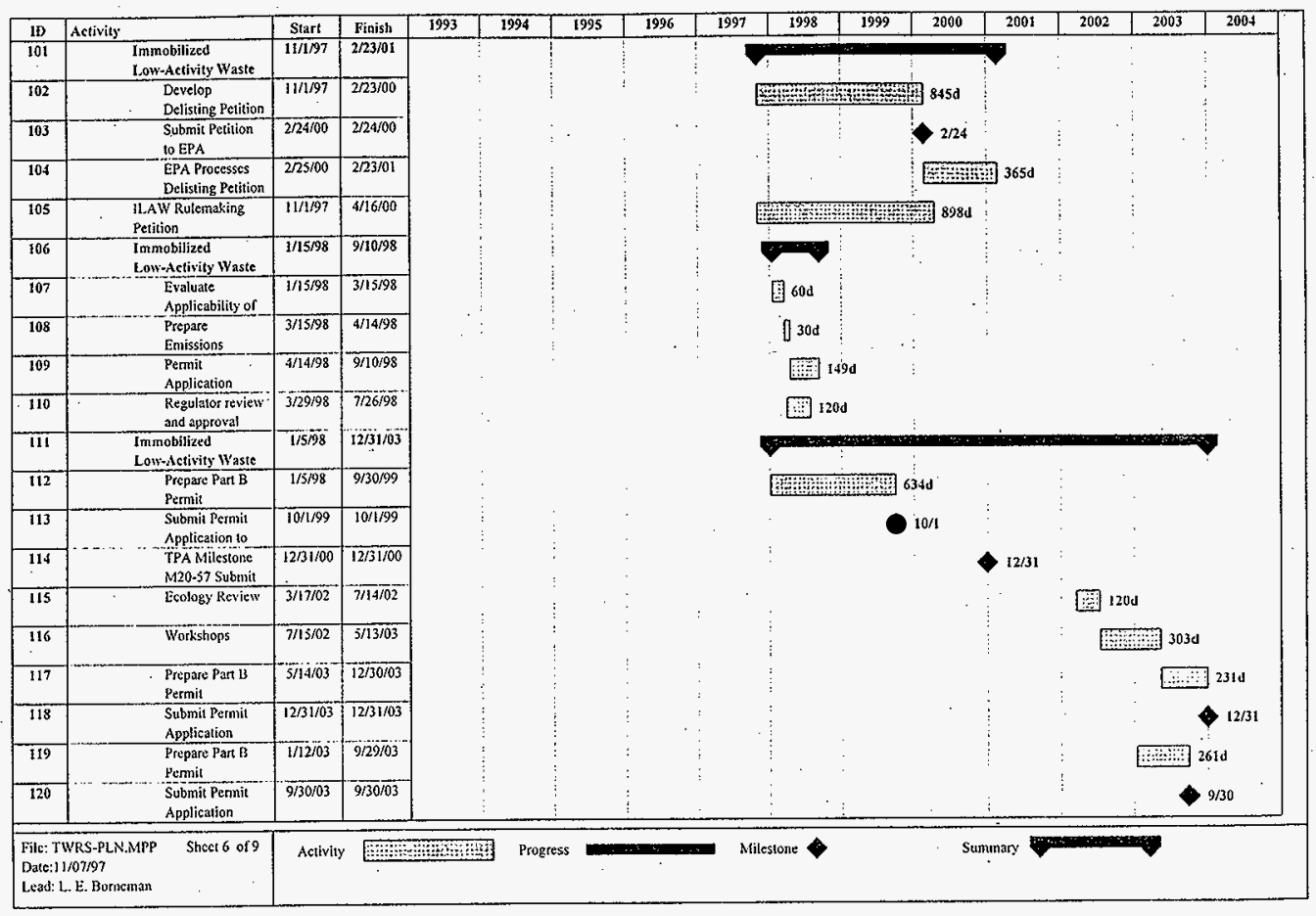




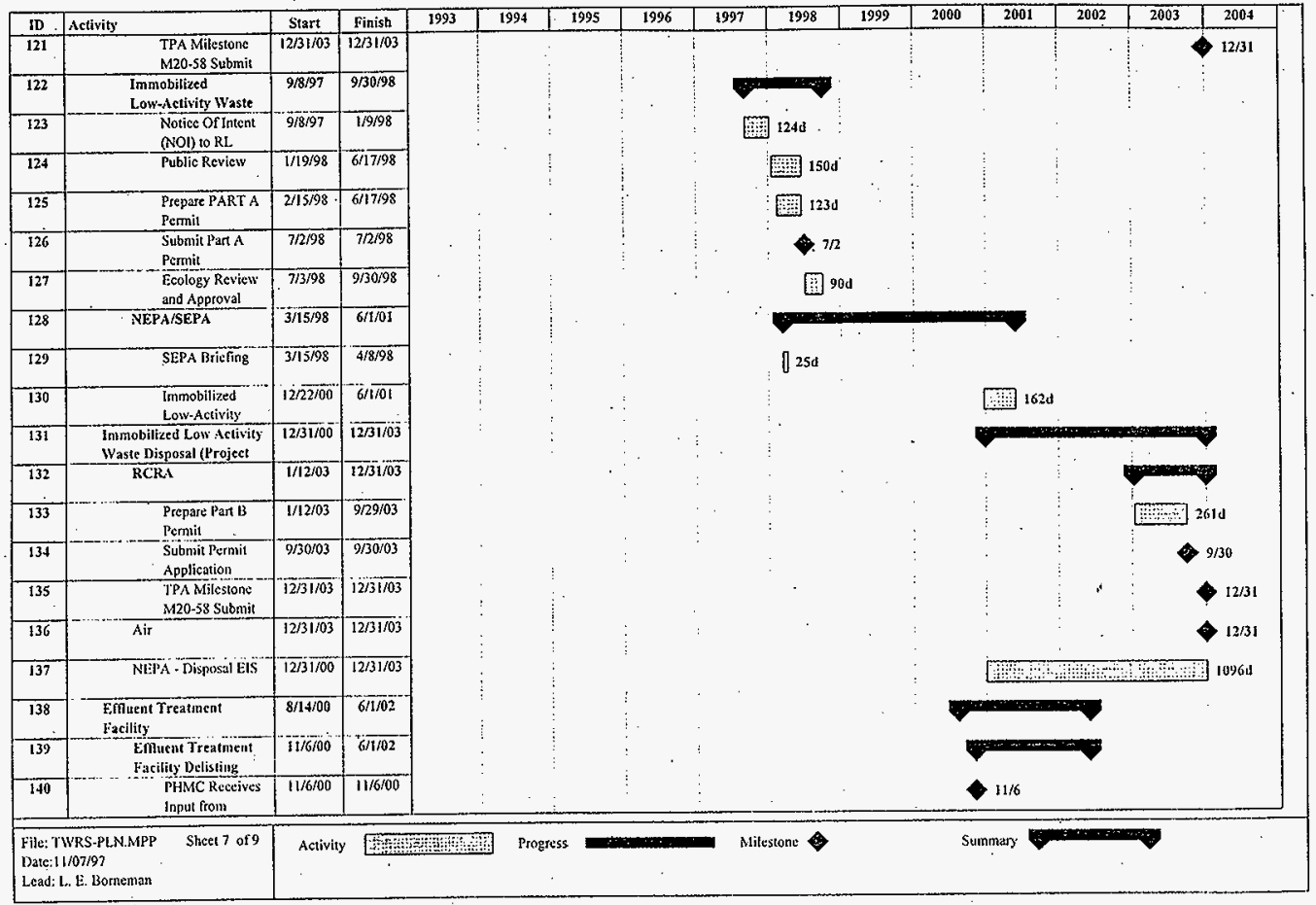




\begin{tabular}{|c|c|c|c|c|c|c|c|c|c|c|c|c|c|c|c|}
\hline ID & Aetivity & Start & Fínish & 1993 & 1994 & 1995 & 1996 & 1997 & 1998 & 1999 & 2000 & 2001 & 2002 & 2003 & 2004 \\
\hline 141 & $\begin{array}{l}\text { Revise Delisting } \\
\text { Petition }\end{array}$ & 1117700 & $5 / 31 / 01$. & & ! & & & & & & & 间 & 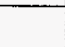 & & \\
\hline 142 & $\begin{array}{l}\text { Submit Revised } \\
\text { Petition to EPA }\end{array}$ & $6 / 1 / 01$ & $6 / 1 / 01$ & & 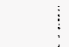 & & & & & & & & & & . \\
\hline 143 & $\begin{array}{l}\text { EPA Processes } \\
\text { Delisting Petition }\end{array}$ & $6 / 2 / 01$ & $6 / 1 / 102$ & 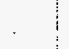 & $\vdots$ & & & & & & & & $365 \mathrm{~d}$ & & \\
\hline 144 & $\begin{array}{l}\text { Effluent Treatment } \\
\text { Facility HF RCRA }\end{array}$ & $12 / 5 / 00$ & $7 / 1 / 0 !$ & & $\vdots$ & & & & & & & & & & \\
\hline 145 & $\begin{array}{l}\text { PHMC Receives } \\
\text { Input from }\end{array}$ & $12 / 5 / 00$ & $12 / 5 / 00$ & 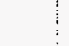 & 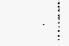 & & & & & & & & & & \\
\hline 146 & $\begin{array}{l}\text { HF Pennit Text } \\
\text { Revision }\end{array}$ & $12 / 6 / 00$ & $6 / 30 / 01$ & 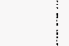 & 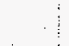 & & & & & & & 20 & & & \\
\hline 147 & $\begin{array}{l}\text { Submit Permit } \\
\text { Modification to }\end{array}$ & $7 / 1 / 01$ & $7 / 1 / 01$ & & $\vdots$ & & & & & & & & & & \\
\hline 148 & $\begin{array}{l}\text { Efluent Treatment } \\
\text { Faeility PARTA }\end{array}$ & $3 / 1 / 01$ & $\overline{9 / 29 / 01}$ & 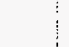 & $\vdots$ & & & & & & & & & & \\
\hline 149 & $\begin{array}{l}\text { Prepare Part A } \\
\text { Form } 3\end{array}$ & $3 \pi 101$ & $6 / 30 \%$ & $\vdots$ & : & & & & & & & & & & \\
\hline 150 & $\begin{array}{l}\text { Subnit Pan A } \\
\text { Permit }\end{array}$ & $7 / 1 / 01$ & $7 / 1 / 01$ & 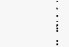 & $\vdots$ & & & & & & & & & . & \\
\hline 151 & $\begin{array}{l}\text { Ecology Review } \\
\text { and Approval }\end{array}$ & $7 / 2 / 01$ & $9 / 29 / 01$ & $\vdots$ & . & & & & & & & & & & \\
\hline 152 & $\begin{array}{l}\text { Emutent Treatment } \\
\text { Facility SWWPP (216). }\end{array}$ & $8 / 14 / 00$ & $\overline{6 / 1 / 01}$ & ; & $\vdots$ & & & & & & & & & & \\
\hline 153 & $\begin{array}{l}\text { PIIMC Receives } \\
\text { laput frons }\end{array}$ & $8 / 14 / 00$ & $8 / 14 / 00$ & 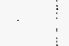 & & & & & & & & & & & \\
\hline 154 & Pemnit Revision & $8 / 15 / 00$ & $2 / 12 / 01$ & ! & & & & & & & & & & & \\
\hline 155 & $\begin{array}{l}\text { RL-Submit } \\
\text { Supplemental }\end{array}$ & $2 / 13 / 01$ & $2 / 13 / 01$ & 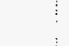 & & & & . & & & & & & & \\
\hline 156 & $\begin{array}{l}\text { Final Permit } \\
\text { Modification }\end{array}$ & $6 / 101$ & $6 / 1 / 01$ & : & & & 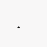 & & - & & & & & & \\
\hline 157 & $\begin{array}{l}\text { Effuent Treatiment } \\
\text { Facility/Liquid }\end{array}$ & $12 / 6 / 100$ & $10 / 1 / 01$ & & & & & & & . & & & & & \\
\hline 158 & $\begin{array}{l}\text { PHMC Reccives } \\
\text { Input frons }\end{array}$ & $\overline{12 / 6 / 00}$ & $\longdiv { 2 / 6 / 0 0 }$ & & $\vdots$ & & . & & & & & & & & \\
\hline 159 & $\begin{array}{l}\text { Prepare } \\
\text { Etnissions }\end{array}$ & $1277 / 00$ & $1 / 5 / 01$ & & $\vdots$ & & & & & & & & & & \\
\hline 160 & $\begin{array}{l}\text { Pernit } \\
\text { Application }\end{array}$ & $1 / 6 / 01$ & $6 / 3 / 01$ & & s & & & & & & & & & & \\
\hline $\begin{array}{l}\text { File: T } \\
\text { Datc: } 1 \\
\text { L.cad: } 1\end{array}$ & $\begin{array}{l}\text { WRS.PLL.MPP Shect } 8 \text { of } 9 \\
\text { 107/97 } \\
\text { E. Bomeman }\end{array}$ & Activily: & W & HEA & Progress & 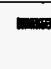 & & Mile & me $\$$ & & & & & & \\
\hline
\end{tabular}


HNF-1773 Rev 1

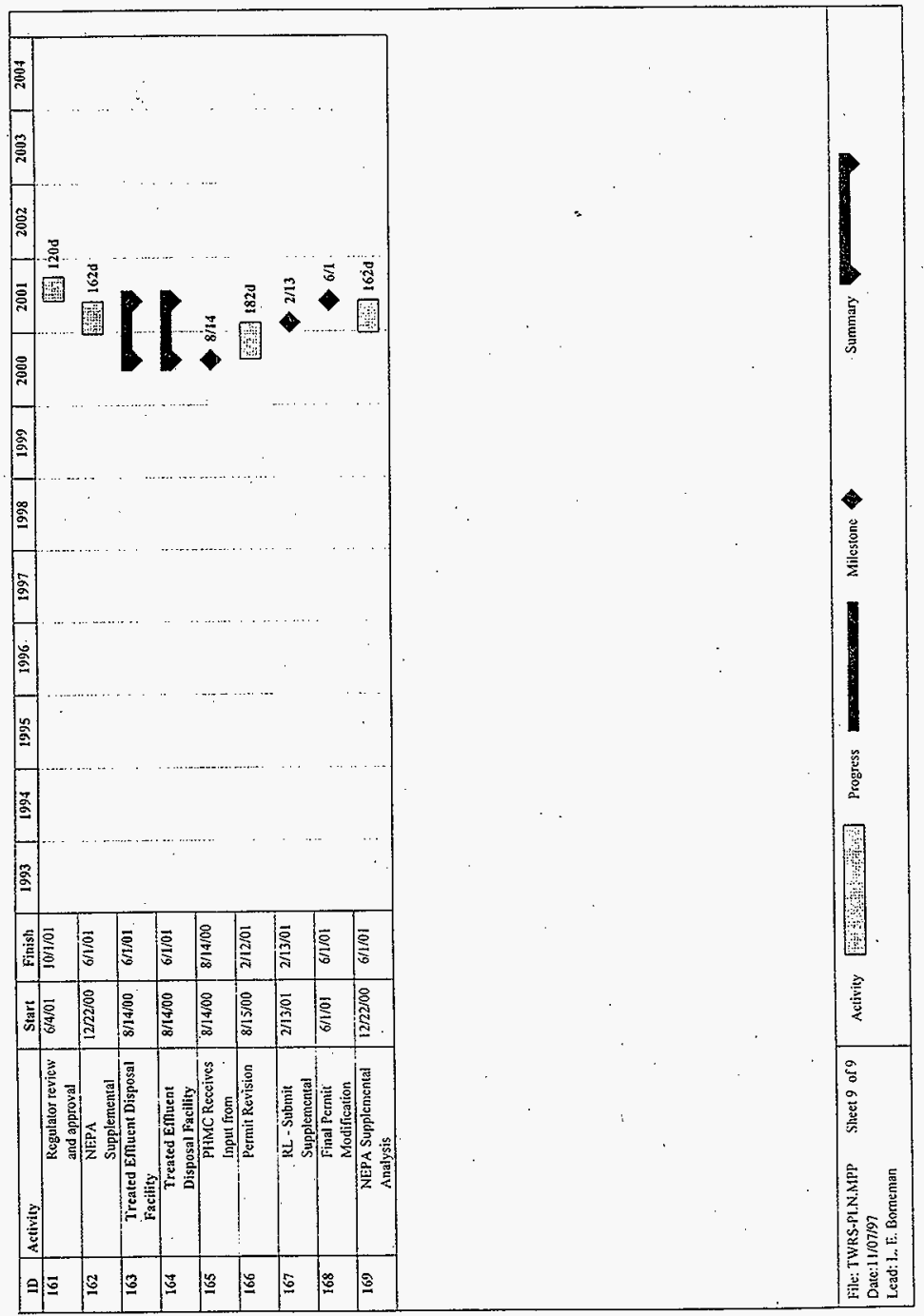


HNF-1773 Rev 1

This page intentionally left blank.

A-10 
HNF-1773 Rev 1

APPENDIX B

INFORMATION NEEDED TO SUPPORT SITEWIDE REPORTING

$\mathrm{B}-\mathrm{i}$ 
HNF-1773 Rev 1

This page intentionally left blank.

B-ii 
Information Needed to Support Sitewide Reporting. (4 Sheets)

\begin{tabular}{|c|c|c|c|c|c|}
\hline . Report & Information needed & $\begin{array}{c}\text { Coordinating } \\
\text { contractor }\end{array}$ & $\begin{array}{l}\text { Required by } \\
\text { contract or } \\
\text { regulations }\end{array}$ & Certifications & $\begin{array}{l}\text { Approximate } \\
\text { due dates }\end{array}$ \\
\hline Annual LDR Report & $\begin{array}{l}\text { Waste inventories and narrative descriptions of TSD units } \\
\text { storing mixed LDR waste }\end{array}$ & PHMC & $\begin{array}{l}\text { TPA } \\
\text { milestone } \\
M-26-01\end{array}$ & None & $\begin{array}{l}\text { To PHMC } 1 / 31 \\
\text { To RL } 4 / 15 \\
\text { To EPA/ } \\
\text { Ecology } 4 / 30\end{array}$ \\
\hline $\begin{array}{l}\text { Hanford Site } \\
\text { Environmental } \\
\text { Report }\end{array}$ & $\begin{array}{l}\text { Compliance with environmental regulations, current site } \\
\text { activities, accomplishments, and issues. Releases of } \\
\text { radionuclides in air/water, hazardous substances, unplanned } \\
\text { environmental releases, inventories of chemicals effluent } \\
\text { monitoring activities and environmental surveillance activities }\end{array}$ & PNNL & DOE Order & None & $\begin{array}{l}\text { To RL by } 7 / 31 \text { of } \\
\text { each year }\end{array}$ \\
\hline $\begin{array}{l}\text { EPCRA Tier II } \\
\text { Emergency and } \\
\text { Hazardous } \\
\text { Chemical Inventory }\end{array}$ & $\begin{array}{l}\text { Provide periodic input on inventory of hazardous materials } \\
\text { with annual verification/certification of information }\end{array}$ & PHMC & Regulations & $\begin{array}{l}\text { Contractors - } \\
\text { Internal } \\
\text { Certification } \\
\text { RL - Certification }\end{array}$ & $\begin{array}{l}\text { To PHMC } 1 / 13 \\
\text { To RL } 1 / 3 \text { ! } \\
\text { To Regltor } 3 / 3\end{array}$ \\
\hline $\begin{array}{l}\text { EPCRA Toxic } \\
\text { Chemical Release } \\
\text { Inventory Report }\end{array}$ & Annual input on use and releases of toxic chemicals & PHMC & Regulations & $\begin{array}{l}\text { Contractors - } \\
\text { Internal } \\
\text { Certification } \\
\text { RL - Certification }\end{array}$ & $\begin{array}{l}\text { To PHMC } 4 / 14 \\
\text { To RL } 6 / 1 \\
\text { To Regltor } 6 / 25\end{array}$ \\
\hline $\begin{array}{l}\text { Annual Dangerous } \\
\text { Waste Report }\end{array}$ & $\begin{array}{l}\text { Provide information on waste generation and waste } \\
\text { management activities }\end{array}$ & PHMC & Regulations & $\begin{array}{l}\text { Contractors - } \\
\text { Internal } \\
\text { Certification } \\
\text { RL - Certification }\end{array}$ & $\begin{array}{l}\text { To PHMC } 1 / 13 \\
\text { To R1, } 1 / 31 \\
\text { To Regltor } 3 / 1\end{array}$ \\
\hline $\begin{array}{l}\text { PCB Annual } \\
\text { Document } \log \end{array}$ & $\begin{array}{l}\text { Information on TSCA-regulated PCB waste is required for the } \\
\text { document log including waste weights and descriptions, } \\
\text { container ID numbers, manifest information for PCBs sent } \\
\text { offsite for disposal, and date of disposal. }\end{array}$ & PHMC & $\begin{array}{l}\text { TSCA } \\
\text { Regulations }\end{array}$ & $\begin{array}{l}\text { None } \\
\text { (Not sent to } \\
\text { regulators) }\end{array}$ & $\begin{array}{l}\text { To [FDH }-4 / 15 \\
\text { To RL }-6 / 15\end{array}$ \\
\hline
\end{tabular}


Information Needed to Support Sitewide Reporting. (4 Sheets)

\begin{tabular}{|c|c|c|c|c|c|}
\hline $\begin{array}{c}\text { Report } \\
.\end{array}$ & Information needed & $\begin{array}{l}\text { Coordinating } \\
\text { contractor }\end{array}$ & $\begin{array}{l}\text { Required by } \\
\text { contract or } \\
\text { regulations }\end{array}$ & Certifications & $\begin{array}{l}\text { Approximate } \\
\text { due dates }\end{array}$ \\
\hline $\begin{array}{l}\text { PCB Annual Status } \\
\text { Report on Storage } \\
\text { of PCBs }\end{array}$ & $\begin{array}{l}\text { Report requires container ID numbers, PCB waste weights and } \\
\text { descriptions, PCB out-of-service dates, and programmatic } \\
\text { information on current or alternative PCB disposal } \\
\text { technologies and data on TSCA-regulated PCB waste that } \\
\text { contains radioactive constituents and PCB waste that contains } \\
\text { both radioactive and RCRA constituents. }\end{array}$ & PHMC & $\begin{array}{l}\text { Compliance } \\
\text { Agreement } \\
\text { with EPA }\end{array}$ & None & $\begin{array}{l}\text { To RL }-11 / 4 \\
\text { To HQ }-12 / 31 \\
\text { To EPA }-2 / 8\end{array}$ \\
\hline $\begin{array}{l}\text { RCRA } \\
\text { Section } 3016 \\
\text { Biennial Report }\end{array}$ & $\begin{array}{l}\text { Data on environmental monitoring, hydrogeologic site } \\
\text { characterization, environmental contamination, and response } \\
\text { actions is required. Also information on RCRA TSD Facilities } \\
\text { that managed hazardous waste on or after November 19, 1980, } \\
\text { including programmatic data and facility descriptions. }\end{array}$ & PHMC & Regulations & None & $\begin{array}{l}\text { To RL }-12 / 15 \\
\text { To HQ }-1 / 15 \\
\text { To EPA }-1 / 31\end{array}$ \\
\hline $\begin{array}{l}\text { Effluent } \\
\text { Information } \\
\text { System-Onsite } \\
\text { Discharge } \\
\text { Information System }\end{array}$ & $\begin{array}{l}\text { DOE requires its sites to annually compile and send } \\
\text { radionuclide release data, for both liquid and airborne } \\
\text { discharges, by April l of each year. }\end{array}$ & PHMC & DOE Order & None & To INEL - 3/31 \\
\hline $\begin{array}{l}\text { Environmental } \\
\text { Releases }\end{array}$ & $\begin{array}{l}\text { This report presents data for radioactive and nonradioactive } \\
\text { substances released into the environment during each calendar } \\
\text { year. Information includes general descriptions of facilities, } \\
\text { summary of nonroutine releases and spills. }\end{array}$ & PHMC & Contract & None & $\begin{array}{l}\text { To RL }-10 \text { days } \\
\text { after the end of } \\
\text { quarter. Internal } \\
\text { document only. }\end{array}$ \\
\hline $\begin{array}{l}\text { Radionuclide Air } \\
\text { Emissions Report }\end{array}$ & $\begin{array}{l}\text { This report includes information on radionuclides emitted to } \\
\text { the atmosphere from Hanford Site facilities, an assessment of } \\
\text { the offsite dose to any member of the public, and descriptions } \\
\text { of point sources }\end{array}$ & PHMC & Regulatory. & $\begin{array}{l}\text { FDH - certifies } \\
\text { RL - certifies }\end{array}$ & $\begin{array}{l}\text { To RL } 6 / 14 \\
\text { To EPA } 6 / 30 \\
\text { To DOE } 6 / 30\end{array}$ \\
\hline
\end{tabular}


Information Needed to Support Sitewide Reporting. (4 Sheets)

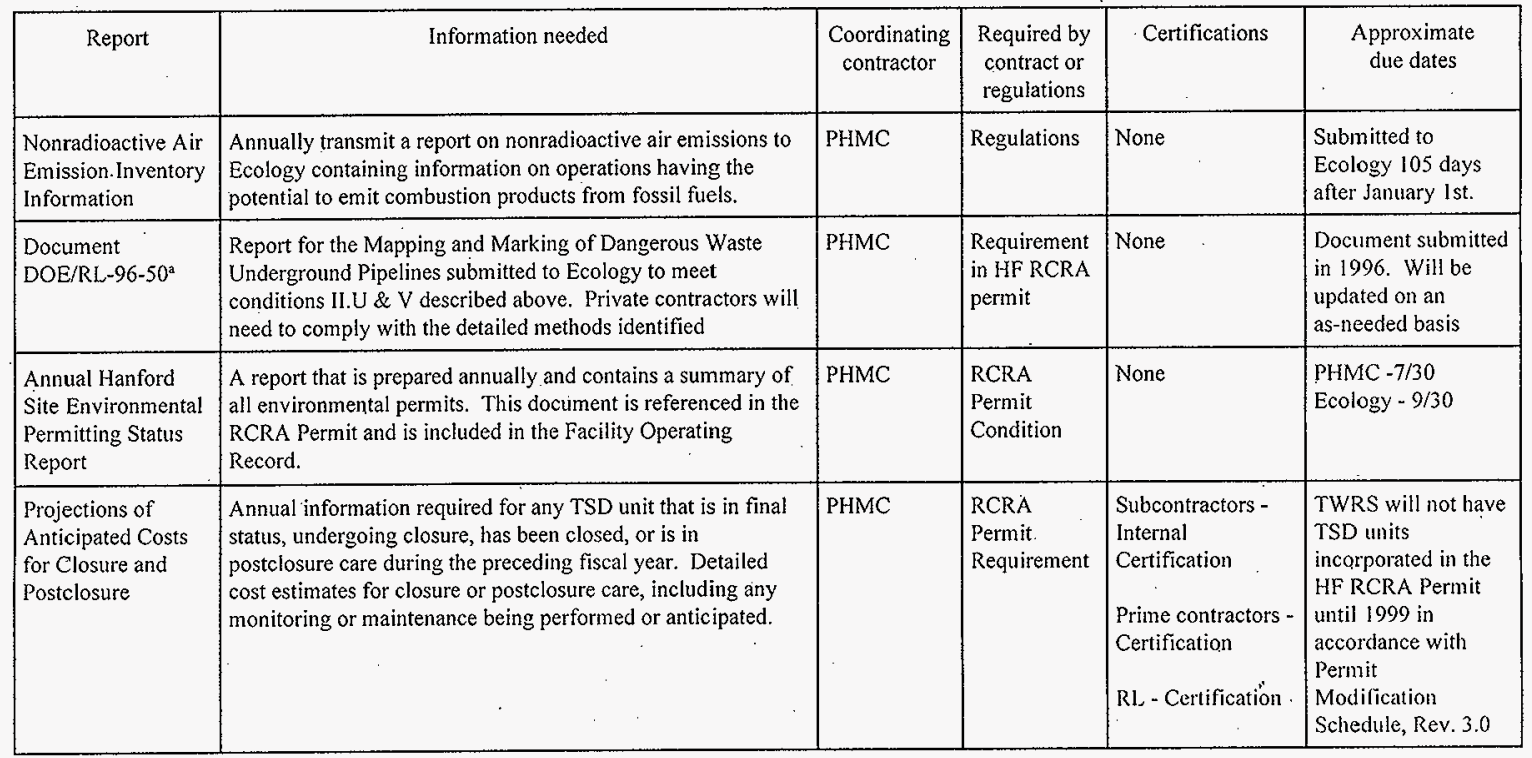


Information Needed to Support Sitewide Reporting. (4 Sheets)

\begin{tabular}{|c|c|c|c|c|c|}
\hline Report & Information needed & $\begin{array}{c}\text { Coordinating } \\
\text { contractor }\end{array}$ & $\begin{array}{c}\text { Required by } \\
\text { contract or } \\
\text { regulations }\end{array}$ & \begin{tabular}{c} 
Certifications \\
Approximate dates \\
\hline
\end{tabular} \\
\hline
\end{tabular}

DOE $=$ U.S. Department of Energy

Ecology $=$ Washington State Department of Ecology.

$E P A=$ U.S. Environmental Protection Agency

EPCRA $=$ Emergency Planning and Community Right-lo-Know Act of $1986 .^{\mathrm{b}}$

FDH = Fluor Daniel Hanford, Inc.

$\mathrm{HF}=$ Hanford Facility.

$H Q=$ U.S. Department of Energy Headquarters

INEL $=$ Idaho National Engineering Laboratory, Idaho Falls, ID.

$\mathrm{LDR}=$ land disposal restrictions.
$\mathrm{PCB}=$ polychlorinated biphenyl.

PHMC $=$ Project Hanford Management Contract.

PNNL $=$ Pacific Northwest National Laboratory.

RCRA $=$ Resource Conservation and Recovery Act of 1976. ${ }^{\circ}$

$\mathrm{RL}=$ U.S. Department of Energy, Richland Operations Office.

TPA $=$ Tri-Party Agreement. ${ }^{\mathrm{d}}$

TSCA $=$ Toxic Substances Control Act of 1976.

TSD $=$ treatment, storage and disposal.

TWRS $=$ Tank Waste Remediation System .

aRL, 1996, Hanford Facility RCRA Permit Condition II. U.1 Report: Mapping of Underground Piping, DOE/RL-96-50, Rev. 0, U.S. Department of Energy,

Richland Operations Office, Richland, Washington.

${ }^{b}$ Emergency Planning and Community Right-to-Know Act of 1986, as amended, 42 USC 11001 et seq.

'Resource Conservation and Recovery Act of 1976, as amended, 42 USC 6901 et seq.

'Ecology, EPA, and DOE, 1996, Hanford Federal Facility Agreement and Consent Order, 2 vols., Washington State Department of Ecology,

U.S. Environmental Protection Agency, and U.S. Department of Encrgy, Olympia, Washington.

'Toxic Substances Control Act of 1976, as amended, 15 USC 2601 et seq. 
HNF-1773 Rev 1

\section{APPENDIX C}

IMPLEMENTING INSTRUCTIONS

C-i 
HNF-1773 Rev 1

This page intentionally left blank. 
Implementation of Lockheed Martin Hanford Corporation Environmental Program. (6 Sheets)

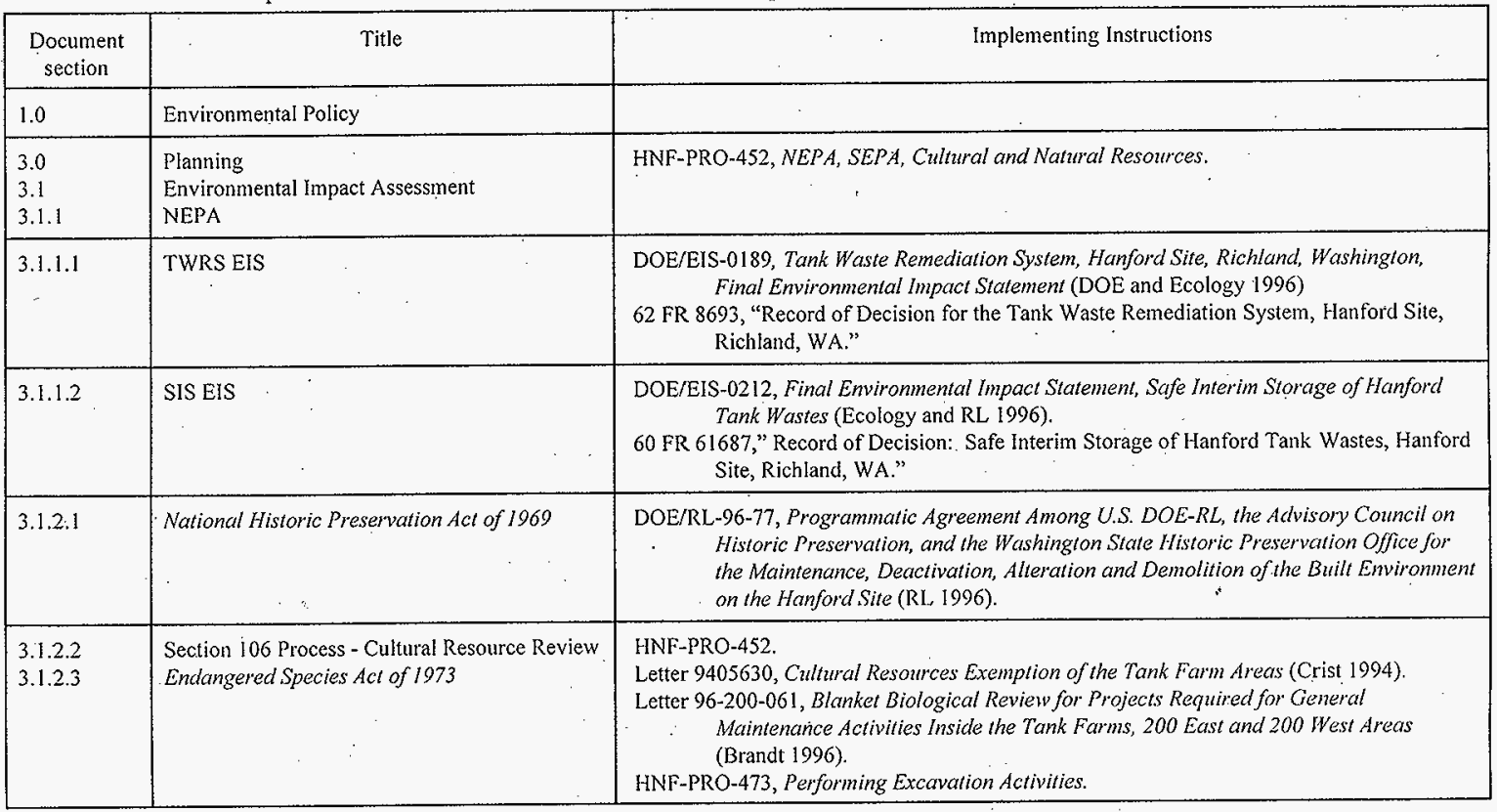


Implementation of Lockheed Martin Hanford Corporation Environmental Program. (6 Sheets)

\begin{tabular}{|c|c|c|}
\hline $\begin{array}{l}\text { Document } \\
\text { section }\end{array}$ & Title & Implementing Instructions \\
\hline $\begin{array}{l}3.2 .1 \\
3.2 .2\end{array}$ & $\begin{array}{l}\text { PHMC Environmental Requirements } \\
\text { Management Process } \\
\text { LMHC Environmental Requirements. } \\
\text { Management Process }\end{array}$ & $\begin{array}{l}\text { HNF-IP-0842, TWRS Administration, Volume VI, "Environmental," Section 2.X, } \\
\text { "Environmental Requirements Management" (Under Development). }\end{array}$ \\
\hline 3.4 & Document Review & $\begin{array}{l}\text { WHC-CM-7-5, Environmental Compliance, Section 13, "Environmental Issue } \\
\text { Identification, Review, and Interface Requirements." }\end{array}$ \\
\hline 3.6 & Budget Planning & $\begin{array}{l}\text { HNF-MD-016, Anntal Budget Submittal (FDH 1997a). } \\
\text { HNF-MD-017, Mulli-Year Work Plan (FDH 1997b). } \\
\text { WHC-CM-2-5, Management Control System, Section 3.7, "Fiscal Year Budget Cycle." }\end{array}$ \\
\hline 4.2 & Training, Awareness, and Competence & $\begin{array}{l}\text { HNF-SD-WM-TR-026, Tank Waste Remediation System Dangerous Waste Training Plan } \\
\text { (Pohto 1997). } \\
\text { HNF-IP-0974, Tank Waste Remediation System Dangerons Waste Training Requirements } \\
\quad \text { Matrices (Hopkinson 1997). } \\
\text { HNF-1P-0842, TWRS Administration, Volume IIl," Training," Section 10.3, "Technical Staff } \\
\quad \text { Qualification" (LMHC 1997). } \\
\text { HNF-IP-0842, Volume III, Section 7.2, "Conduct of On-The-Job Training" (LMHC 1997) }\end{array}$ \\
\hline $\begin{array}{l}4.3 \\
4.3 .1\end{array}$ & $\begin{array}{l}\text { Operational Control } \\
\text { Procedure Upgrades to Reflect Changed } \\
\text { Requirements or Permit Conditions }\end{array}$ & $\begin{array}{l}\text { HNF-IP-0842, Volume VI, "Environmental," Section 1.2, "Field Implementation of } \\
\text { Environmental Notices of Construction for Air Emission Units Operated by } \\
\text { TWRS" (LMHC 1997). }\end{array}$ \\
\hline 4.3 .2 & $\begin{array}{l}\text { Implementation of Hanford Site Wide RCRA } \\
\text { Permit }\end{array}$ & WA7890008967, Hanford Site RCRA Permit (Ecology and EPA 1994) \\
\hline 3.32 & Regulatory Approvals for Air Permits & DOE/RL-95-07, Hanford Sile Air Operating Permit Application (RL 1995). \\
\hline
\end{tabular}


Implementation of Lockheed Martin Hanford Corporation Environmental Program. (6 Sheets)

\begin{tabular}{|c|c|c|}
\hline $\begin{array}{l}\text { Document } \\
\text { section }\end{array}$ & Title & Implementing Instructions \\
\hline $\begin{array}{l}4.3 .3 \\
4.3 .3 .1 \\
4.3 .3 .2 \\
4.3 .3 .3\end{array}$ & $\begin{array}{l}\text { Solid Waste Management } \\
\text { Lead Management Plan } \\
\text { Contaminated Equipment } \\
\text { Reusable Equipment }\end{array}$ & $\begin{array}{l}\text { HNF-PRO-455, Solid Waste Management. } \\
\text { HNF-IP-0842, Volume VI, Section 1.1, "Lead Management Plan" (LMHC 1997). } \\
\text { HNF-IP-0842, Volume VI, Section 3.3, "Reusable Equipment" (LMHC 1997). } \\
\text { HNF-IP-0842, Volume VI, Section 4.2, "Waste Generating Plan" (LMHC 1997). } \\
\text { TO-100-002, Preparing Waste Containers/Packages and Establishing Satellite } \\
\quad \text { Accumulation Areas. } \\
\text { TO-100-010, Waste Truck Support Services. } \\
\text { TO-100-045, Perform Inspections of Active Packages, Satellite Accumulalion Areas, } \\
\quad \text { Storage Areas, and Related Tasks. } \\
\text { TO-100-052, Perform Waste Generation, Segregation, and Accumulation. } \\
\text { TO-100-053, Perform Sampling, Repackaging and Shielding of Waste Packuges. } \\
\text { TO-100-056, Operate the Low Level Waste and Non-Regulated Storage Pads and Perform } \\
\quad \text { Supporting Tasks. } \\
\text { TO-100-065, Operate and Inspect the Less Than 90 Day Storage Pads and Related Tasks. } \\
\text { TO-100-210, Perform Dispatch/Container Document System Duties. } \\
\text { WHC-SD-WM-PLN-098, TWRS Contaminated Equipment Management Plan (WHC 1996). }\end{array}$ \\
\hline $4: 4$ & Pollution Prevention and Waste Minimization & HNF-PRO-462, Pollution Prevention. \\
\hline 4.5 & Underground Storage Tank Management & WAC 173-360, "Underground Storage Tank Regulations." \\
\hline 4.6 & Emergency Preparedness and Response & WHC-IP-0263-TF, Tank Farms Building Emergency Plan (Rowland 1994). \\
\hline 5.2 & Spill and Release Reporting & $\begin{array}{l}\text { HNF-PRO-453, Environmental Notification and Reporting, Section 2.1, "Spill and Release } \\
\text { Reporting." }\end{array}$ \\
\hline 5.3 & Records & HNF-PRO-453, Section 2.5, "Record and Reporting Requirements." \\
\hline
\end{tabular}


Implementation of Lockheed Martin Hanford Corporation Environmental Program. (6 Sheets)

\begin{tabular}{|l|l|l|}
\hline $\begin{array}{c}\text { Document } \\
\text { section }\end{array}$ & \multicolumn{1}{|c|}{ Title } & \multicolumn{1}{|c|}{ Implementing Instructions } \\
\hline 6.1 .1 & Effluent Monitoring & $\begin{array}{c}\text { WHC-EP-0479-1, Facility Effluent Monitoring Plan for Tank Farm Facility (Bachand and } \\
\text { Crummel 1995). }\end{array}$ \\
\hline 6.2 & $\begin{array}{l}\text { Compliance Assessments/Corrective Action } \\
\text { Management }\end{array}$ & $\begin{array}{l}\text { HNF-IP-0842, Volume VI, Section 2.1, "Scheduling, Planning, and Conducting } \\
\text { Surveillance/Compliance Inspections" (LMHC I997) } \\
\text { HNF-IP-0842, Volume VI, Section 2.x, "Functional Assessment" (under development). } \\
\text { HNF-IP-0842, Volume VI, Section 2.x, "Management Appraisals" (under development). }\end{array}$ \\
\hline
\end{tabular}

Acts

Endangered Species Act of 1973, as amended, 16 USC 153! et seq.

National Environmental Policy Act of 1969 , as amended, 42 USC 4321 et seq.

Federa! Register

60 FR 61687, 1995, "Record of Decision: .Safe Interim Storage of Hanford Tank Wastes, Hanford Site, Richland, WA," Federal Register, Vol. 60, pp. 61687.6I692 (Decenter 1)

62 FR 8693, 1997, "Record of Decision for the Tank Waste Remediation System, Hanford Site, Richland, WA," Federal Register, Vol. 62, pp. 8693-8704 (February 26).

Procedtures

HNF-PRO-452, NEPA, SEPA, Cultural and Natural Resources, Fluor Danicl Hanford, Inc., Richland, Washington.

HNF-PRO-453, Environmental Notification and Reporting. Fluor Daniel Hanford, Inc., Richland, Washington.

HNF-PRO-455, Solid Waste Management, Fluor Daniel Hanford, Inc., Richland, Washington.

HNF-PRO-462, Pollution Prevention, Fluor Daniel Hanford, Inc., Richland, Washington.

HNF-PRO-473, Performing Excavation Acrivities, Fluor Daniel Hanford, [nc., Richland, Washington.

Washington Administrative Code

WAC 173-360, "Underground Storage Tank Regulations," Washington Administrative Code, as amended.

Controlled Manuals

WHC-CM-2-5, Section 3.7, "Fiscal Year Budget Cycle," Management Control Syslem, Westinghouse Hanford Company, Richland, Washington.

WHC-CM-7-5, Environmental Compliance, Section 13.0, "Environmental Issue Identification, Review, and Interface Requirements," Westinghouse Hanford Company, Richland, Washington. 
Implementation of Lockheed Martin Hanford Corporation Environmental Program. (6 Sheets)

\begin{tabular}{|c|c|c|}
\hline $\begin{array}{c}\text { Document } \\
\text { section }\end{array}$ & Title & Implementing Instructions \\
\hline
\end{tabular}

Tank Farm Procedures

TO-100-002, Preparing Waste Containers/Packages and Establishing Satellite Accumulation Areas, prepared by Lockheed Martin Hanford Corporation for Hluor Daniel Ilanford, Inc.,

Richland, Wasinington.

TO-100-010, Waste Truck Support Services, prepared by Lockheed Martin I fanford Corporation for Fluor Daniel Ianford, Inc., Richland, Washington.

TO-100-045, Perform Inspections of Active Packages, Satellite Acctumulation Areas, Storage Areas, and Related Tasks, prepared by Lockheed Martin Hanford Corporation for Hluor Daniel

Ianford, Inc., Richland, Washington.

TO-100-052, Perform Waste Generation, Segregation, and Accumulation, prepared by Lockheed Martin Hanford Corporation for Fluor Danicl Hanford, Inc., Richland, Washington.

TO-100-053, Perform Sampling, Repackaging and Shielding of Waste Packages, prepared by Lockheed Martin Hanford Corporation for Fluor Daniel Hanford, Inc., Richland, Washington.

TO-100-056, Operate the Low Level Waste and Non-Regulated Storage Pads and Perform Supporting Tasks, prepared by Lockhced Martin Hanford Corporation for Fluor Danicl Hanford, Inc., Richland, Washington.

Waslington.

TO-100-065, Operate and Inspect the Less Than 90 Day Storage Pads and Related Tasks, prepared by Lockheed Martin Hanford Corporation for Fluor Danicl Han ford, Inc., Richland, "

TO-100-210, Perform Dispatch/Container Document System Duties, prepared by Lockheed Martin Hanford Corporation for Fluor Danis] Hanford, Inc., Richland, Washington.

Documents

Brandt, C. A., 1996, Blanket Biological Review for Projects Required for General Maintenance Activities Inside the Tank Farms, 200 East and 200 West dreas (letter $96-200-061$ to

K. Moss, Westinghouse J Iantord Company, May 10), Pacific Northwest National Laboratory, Richland, Washington.

Bachand, D. D., and G. M. Crummel, 1995, Facility Effuent Moniloring Plan for Tank Farm Facility, WHC-EP-0479-1, Westinghouse Ilanford Company, Richland, Washington.

Crist, M. E., 1994, Cultural Resources Exemption of the Tank Farm Areas (letter 9405630 to W. B. Bancroft, Westinghouse Hanford Company, August 16) U.S. Department of Energy,

Richland Operations Office, Richland, Washington.

DOE and Ecology, 1996, Tank Wasfe Remediation System, Hanford Site, Richland, Washington, Final Environnental Impact Statement, DOE:/EIS-0189, U.S. Departmemt of Energy and Washington State Department of Ecology, Washington, D.C.

Ecology and IPA, 1994, Ihanford Facility RCRA Permil, WA7890008967, as nodified, Washington State Department of Ecology and U.S. Environmental Protection Ageney, Olympia.

Washington.

Ecology and RL, 1996, Final Environmenul Impaci Statomem, Safe Interim Storage of Itanford Tank Wastes, DOr/BIS-0212, Washiugton State Department of Ecology and

U.S. Department of Energy, Richland Operations Oftice, L.accy, Washington.

FDH, 1997a, Annual Budget Subminal, IINI-MD-016, Rev, 0, Fluor Daniel Hanford, Inc., Richland, Washington.

FDH, 1997b, Multi-Year Work Plan, HNF-MD-017, Rev. 0, Fluor Daniel Hanford, Ine., Richland, Washington.

Hopkinson, W. G., 1997, HNF-IP-0974, Tank Waste Remediation System Dangerous Waste Training Requirements Matrices, HNF-IP-0974, Rev. 9, prepared by I.ocklheed Martin I hanford

Corporation for Fluor Danicl Hanford, Inc., Richland, Washington.

LMHC, 1997, TWRS Administration, WHC-IP-0842, Fluor Danicl Flauford, Inc., Richland Washington.

Mulkey, C. H., 1996, Double-Shell Tank IVasie Analysis Plan, WHC-SD-WM-EV-053, Rev. 4, Westinghouse Hanford Company, Richland, Washington.

Pohto, R. E, 1997, Tank Waste Remediation System Dangerons Waste Training Plan, HNF-SD-WM-TR-026, Rev. 6, prepared by Lockheed Martin llanford Corporation tor liluor Daniel

Ilanford, Inc., Richland, Washington.

Rl, 1996, Programmatic Agreement Among the U.S. DOE-RL the Advisory Council on Historic Preservation, and the Wastington State Historic Preservation Office for the Maintenamce

Decctivation, Alleration and Demolifion of the Buill Environment on the Fanford Site, DOE/RL-96-77, U.S. Department of Energy, Richland Operations Otfice, Richland, Washington. 
Implementation of Lockheed Martin Hanford Corporation Environmental Program. (6 Sheets)

\begin{tabular}{|c|c|c|c|}
\hline $\begin{array}{c}\text { Document } \\
\text { section }\end{array}$ & Title & Implementing Instructions \\
\hline
\end{tabular}

RL, 1995, Hanford Site Air Operating Permit Application, DOE/RL-95-07, Rev. 0, U.S. Department of Energy, Richland Operations Office, Richland, Washington. Rowland, D. J, 1994, Tank Farms Building Emergency Plan, WHC-IP-0263-TF, Rev. 2, Westinghouse Hanford Company, Richland, Washington.

WHC, 1996, TWRS Contaminated Equipment Management Plan, WHC-SD-WM-PLN-098, Rev. 1, Westinghouse Hanford Company, Richland, Washington.

EIS = Environmental Impact Statement.

$\mathrm{IR}=$ Federal Register

LMHC $=$ Lockheed Martin Hanford Corporation.

$N E P A=$ National Environmental Policy Act.

PHMC = Project Hanford Management Contract.
RCRA = Resource Conservation and Recovery Act.

RL $=$ U.S. Department of Energy, Richland Operations Office.

SEPA = State (of Washington) Environmental Policy Act

SIS $=$ safe interim storage.

TWRS $=$ Tank Waste Remediation System 
HNF-1773 Rev 1

APPENDIX D

GUIDANCE AND REQUIREMENTS TO

DELIVERABLES CROSSWALK

TWRS Environmental Program Plan

D-i 
HNF-1773 Rev 1

This page intentionally left blank.

D-ii 
Table D-1. Guidance and Requirements to Deliverables Crosswalk TWRS Environmental Program Plan.

\begin{tabular}{|c|c|c|}
\hline Guidance or Requirement & Status & Implementing Location \\
\hline $\begin{array}{l}\text { A.1 DOE Letter to H.J. Hatch, FDH, from W. J. } \\
\text { Taylor, DOE, dated August } 8,1997, \# 9757162 \mathrm{~A}(36) \\
\text { ITEM CHECKIIST) }\end{array}$ & & \\
\hline $\begin{array}{l}\text { 32. Environmental permits and safety authorization } \\
\text { bases are in place as required for authorization-to- } \\
\text { proceed decision. }\end{array}$ & I & Section 4.3 \\
\hline $\begin{array}{l}\text { A.3 DOE Letter H. J Hatch, FDH, from William } \\
\text { J. Taylor, DOE, dated December } 2,1997, \$ 9761291\end{array}$ & & क्या \\
\hline $\begin{array}{l}\text { 5. Provide specific information to address the ten } \\
\text { areas in Paragraph } 4.2 .4 \text { of the August } 8 \mathrm{DOE} \text { letter of } \\
\text { direction }\end{array}$ & & . \\
\hline $\begin{array}{l}\text { j. Deliver to DOE or make available for DOE review, } \\
\text { Draft Program Plans }\end{array}$ & I & Entire Document \\
\hline $\begin{array}{l}\text { B.1 DOE Order } 430,1, \text { Good Practice Gude }^{\prime \prime} \\
\text { GPG-FM-002 }\end{array}$ & & \\
\hline 2.2.6 ES\&H Program Plan & $\mathrm{I}$ & Entire Document. \\
\hline 2.3.6 Environment, Safety and Health Criteria & I & Entire Document. \\
\hline 2. Permits, Licenses, and Regulatory Approval & $\mathrm{I}$ & Section 4.3 and Appendix A \\
\hline 2.4.6 Environment, Safety and Health Criteria & $\mathrm{I}$ & Entire Document. \\
\hline 4. Permits, Licenses, and Regulatory Approval & $I$ & Section 4.3 and Appendix A \\
\hline 2.5.6 Environment, Safety and Health Criteria & I & Entire Document. \\
\hline 3. D\&D Plans & $\mathrm{I}$ & Appendix A and Section 8.0 \\
\hline $\begin{array}{l}\text { B. } 2 \text { DoE Order } 425.1, \text { Start-Up and Restart of } \\
\text { Nuclear Facilities, Section 4.d.(1)-(20) }\end{array}$ & 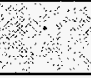 & \\
\hline $\begin{array}{l}425.1 \text { Core Requirement (14) - ES\&H Site-Wide } \\
\text { Safety Culture }\end{array}$ & I & Entire Document \\
\hline C.1 Interface Control Documents & $\therefore$ & क \\
\hline 9. Land for Siting & + & \\
\hline $\begin{array}{l}\text { 3. Establish baseline site and environmental } \\
\text { conditions through a third party. }\end{array}$ & $I$ & Section 4.1 \\
\hline $\begin{array}{l}\text { 4. Ensure that site-use satisfies requirements through } \\
\text { the environmental checklist process at the initiation of } \\
\text { Part B. }\end{array}$ & I & Section 4.1 \\
\hline
\end{tabular}


Table D-1. Guidance and Requirements to Deliverables Crosswalk TWRS Environmental Program Plan.

\begin{tabular}{|c|c|c|}
\hline \multirow{2}{*}{$\begin{array}{r}\text { Guidance or Requirement } \\
\text { 16. }{ }^{{ }^{90} \text { Strontium/Transuranics/Entraine }}\end{array}$} & Status & Implementing Location \\
\hline & \multicolumn{2}{|c|}{ 16. ${ }^{90}$ Strontium/Transuranics/Entraine } \\
\hline $\begin{array}{l}\text { 1. Receive the } 90 \mathrm{Sr} / \mathrm{TRU} \text {, Entrained Solids, and } \\
\text { transfer line flush water. }\end{array}$ & I & Section 5.3 .4 \\
\hline $\begin{array}{l}\text { 22. Air Emissions - Permits } \\
\text { D.1 Detailed Instructions for Assessment of RTP- } \\
\text { Appendix C, November } 14,1997\end{array}$ & I & Section 4.3.2 and Appendix A \\
\hline \multicolumn{3}{|l|}{$\begin{array}{l}\text { D. } 1 \text { Detailed Instructions for Assessment of RTP. } \\
\text { Appendix C, November } 14,1997\end{array}$} \\
\hline $\begin{array}{l}\text { 30. Show that the PHMC Team is on schedule for } \\
\text { completing regulatory-compliance-related documents } \\
\text { supporting the private contractor(s). }\end{array}$ & I & Appendix A \\
\hline \multicolumn{3}{|l|}{$\begin{array}{l}\text { D. } 2 \text { Plan for Determining PHMC Tean's RTP for } \\
\text { Waste Feed Delivery (Table 2). }\end{array}$} \\
\hline \multicolumn{3}{|l|}{$\begin{array}{l}\text { PHMC provide deliverables necessary to support } \\
\text { RTP, as follows: }\end{array}$} \\
\hline 28. W-151 Notification of Startup (EPA) & I & Appendix A and Section 4.3 \\
\hline 29. Retrieval Permit Incorporate Comments & $\mathrm{I}$ & Appendix $\mathrm{A}$ and Section 4.3 \\
\hline \multicolumn{3}{|l|}{$\begin{array}{l}\text { D.3 Plan for Determining PHMC-Team RTP for } \\
\text { Waste Feed Delivery pocument Checklist } \\
\text { (Table } 3 \text { ) }\end{array}$} \\
\hline $\begin{array}{l}\text { 16. Plans support post-closure monitoring from } \\
2034 \text { to } 2064 \text {. }\end{array}$ & I & Sections 4.3 .1 .2 and 8.0 \\
\hline $\begin{array}{l}\text { 20. Plans are to receive the } \mathrm{Tc} / \mathrm{Sr} / \mathrm{TRU} \text { and entrained } \\
\text { solids back from the single-LAW-processing-plant } \\
\text { private contractor. }\end{array}$ & I & Section 5.3 \\
\hline $\begin{array}{l}\text { 37. Plans assume residual waste in the tanks will be } \\
\text { classified as "Incidental Waste" by the NRC to } \\
\text { support closure plans and performance assessments. }\end{array}$ & I & Section 4.3 .1 .2 \\
\hline $\begin{array}{l}\text { 39. Plans assume an EIS (or supplemental EIS) will } \\
\text { be required for closure, and landfill closure in the } \\
200 \text { areas will be authorized. }\end{array}$ & I & Section 4.3.1.2 and Appendix A \\
\hline $\begin{array}{l}\text { 57. Plans include performing alternative analyses } \\
\text { needed to support the ATP decision and TWRS } \\
\text { Program review per EIS ROD. }\end{array}$ & I & Section 4.3.1.1 \\
\hline $\begin{array}{l}\text { 61. Plans include completion of SST Retrieval } \\
\text { System CDR, including sys def, leak detection } \\
\text { mitigation and monitoring as required per TPA. }\end{array}$ & I & Sections $2.0,4.2$ and 4.3 \\
\hline
\end{tabular}


Table D-1. Guidance and Requirements to Deliverables Crosswalk TWRS Environmental Program Plan.

\begin{tabular}{|c|c|c|}
\hline Guidance or Requirement & Status & Implementing Location \\
\hline $\begin{array}{l}\text { 68. Plans include PHMC interface w/ DOE, EPA and } \\
\text { Mgmt Sys Div (MSD) on closure strategy dev / } \\
\text { closure EIS. }\end{array}$ & I & $\begin{array}{l}\text { Sections } 2.0,4.3 .1 .2,8.0 \text {, and } \\
\text { Appendix A }\end{array}$ \\
\hline $\begin{array}{l}\text { D.8 Draft Plan for Determining RTP for } \\
\text { Infrastructure \& Byproducts Delivery, } \\
\text { Appendix C, Tnfrastructure (Management } \\
\text { Baseline) Checklist }\end{array}$ & & का? \\
\hline $\begin{array}{l}\text { 45. Show acceptable environmental permits and } \\
\text { safety bases are in place. }(1.3 .1-1.3 .2)\end{array}$ & $I$ & Section 4.3 and Appendix A \\
\hline $\begin{array}{l}\text { 47. Indicate that support is planned/budgeted for } \mathrm{RL} \\
\text { preparation of NEPA docs. }(1.3 .5)\end{array}$ & I & Section 4.1.1 \\
\hline $\begin{array}{l}\text { D.11 Draft Plan for Determining RTP for } \\
\text { Infrastructure \& Byproducts Delivery, } \\
\text { Appendix E, Infrastructure Feed Tank Transfer } \\
\text { (Management Baseline) Checklist. }\end{array}$ & 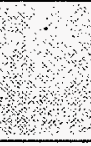 & का \\
\hline $\begin{array}{l}\text { 89. Show acceptable environmental permits and } \\
\text { safety bases are in place. }(1.3 .1-1.3 .2)\end{array}$ & I & Appendix A \\
\hline $\begin{array}{l}\text { 91. Indicate that support is planned/budgeted for RL } \\
\text { preparation of NEPA docs. (1.3.5) }\end{array}$ & $I$ & Section 4.1 .1 \\
\hline $\begin{array}{l}\text { E1 TWRS Waste Disposal Division Planning } \\
\text { Guidance dated July } 7,1997 \text { (Updated } \\
\text { December 12,1997) }\end{array}$ & $\mathrm{k}$ & \\
\hline $\begin{array}{l}\text { Complete design activities and safety studies to } \\
\text { support the installation of mixer pumps in AP-102, } \\
\text { AP-104 and AN-105. }\end{array}$ & $\mathrm{I}$ & Section 4.3 and Appendix A \\
\hline $\begin{array}{l}\text { The Storage and Disposal project will ensure the } \\
\text { requirements in paragraph } 3.4 .2 \text { are met. }\end{array}$ & $\mathrm{I}$ & Section 2.0 \\
\hline
\end{tabular}


HNF-1773 Rev 1

This page intentionally left blank.

D-4 


\section{DISTRIBUTION SHEET}

\begin{tabular}{|c|c|c|c|c|c|}
\hline \multirow{2}{*}{$\begin{array}{l}\text { To } \\
\text { Document Control Services }\end{array}$} & \multirow{2}{*}{$\begin{array}{l}\text { From } \\
\text { TWRS Configl }\end{array}$} & & & \multicolumn{2}{|c|}{ Page 1 of 1} \\
\hline & & tion Mana & gent & \multicolumn{2}{|c|}{ Date January 3, 1998} \\
\hline \multirow{2}{*}{\multicolumn{4}{|c|}{$\begin{array}{l}\text { Project Title/Work Order } \\
\text { Tank Waste Remediation Systems (HNF-1773) }\end{array}$}} & \multirow{2}{*}{\multicolumn{2}{|c|}{$\begin{array}{l}\text { EOT No. } \\
\text { ECN No. } 644866\end{array}$}} \\
\hline & & & & & \\
\hline Name & MSIN & $\begin{array}{l}\text { Text } \\
\text { With Alr } \\
\text { Attach. }\end{array}$ & $\begin{array}{l}\text { Text } \\
\text { On7y }\end{array}$ & $\begin{array}{l}\text { Attach./ } \\
\text { Appendix } \\
\text { Only }\end{array}$ & $\begin{array}{l}\text { EDT/ECN } \\
\text { Only }\end{array}$ \\
\hline
\end{tabular}

J.N. Alibert

M.P. Delozier

0. A. Halvorson

J.0. Honeyman

K.N. Jordan

R.J. Murkowski

M.A. Payne

R.W. Powel1

R.P. Raven

R.E, Raymond

S.H. Rifaey

B. Root

R.L. Treat

J.M. Vann

J.H. Wicks Jr

R.D. Wojtasek
$52-48 \quad x$

R2-58 $X$

G3-21 $\quad X$

G3-21 $\quad X$

G3-21 $\quad X$

H6-37 $X$

$R 2-58 \quad X$

H5-03 $X$

R1-51 $X$

R2-38 $\quad X$

R1-56 $X$

G3-21 $X$

H5- $03 \quad X$

H6-37 $\quad X$

H7-07 $\quad X$

G3-21 $X$

Central Files

BT-07 $\quad X$

